\title{
Potential of Climate Change and Herbivory to Affect the Release and Atmospheric Reactions of BVOCs from Boreal and Subarctic Forests
}

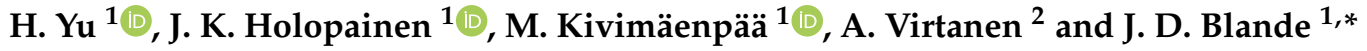 \\ 1 Department of Environmental and Biological Sciences, University of Eastern Finland, P.O. Box 1627, \\ 70211 Kuopio, Finland; hao.yu@uef.fi (H.Y.); jarmo.holopainen@uef.fi (J.K.H.); \\ minna.kivimaenpaa@uef.fi (M.K.) \\ 2 Department of Applied Physics, University of Eastern Finland, P.O. Box 1627, 70211 Kuopio, Finland; \\ annele.virtanen@uef.fi \\ * Correspondence: james.blande@uef.fi; Tel.: +358-403553210
}

Citation: Yu, H.; Holopainen, J.K.; Kivimäenpää, M.; Virtanen, A.; Blande, J.D. Potential of Climate Change and Herbivory to Affect the Release and Atmospheric Reactions of BVOCs from Boreal and Subarctic Forests. Molecules 2021, 26, 2283. https://doi.org/10.3390/ molecules 26082283

Academic Editors: Andrea Liliana Clavijo McCormick, Ülo Niinemets and Velemir Ninkovic

Received: 4 March 2021

Accepted: 12 April 2021

Published: 15 April 2021

Publisher's Note: MDPI stays neutral with regard to jurisdictional claims in published maps and institutional affiliations.

Copyright: (c) 2021 by the authors. Licensee MDPI, Basel, Switzerland. This article is an open access article distributed under the terms and conditions of the Creative Commons Attribution (CC BY) license (https:// creativecommons.org/licenses/by/ $4.0 /)$.

\begin{abstract}
Compared to most other forest ecosystems, circumpolar boreal and subarctic forests have few tree species, and are prone to mass outbreaks of herbivorous insects. A short growing season with long days allows rapid plant growth, which will be stimulated by predicted warming of polar areas. Emissions of biogenic volatile organic compounds (BVOC) from soil and vegetation could be substantial on sunny and warm days and biotic stress may accelerate emission rates. In the atmosphere, BVOCs are involved in various gas-phase chemical reactions within and above forest canopies. Importantly, the oxidation of BVOCs leads to secondary organic aerosol (SOA) formation. SOA particles scatter and absorb solar radiation and grow to form cloud condensation nuclei (CCN) and participate in cloud formation. Through BVOC and moisture release and SOA formation and condensation processes, vegetation has the capacity to affect the abiotic environment at the ecosystem scale. Recent BVOC literature indicates that both temperature and herbivory have a major impact on BVOC emissions released by woody species. Boreal conifer forest is the largest terrestrial biome and could be one of the largest sources of biogenic mono- and sesquiterpene emissions due to the capacity of conifer trees to store terpene-rich resins in resin canals above and belowground. Elevated temperature promotes increased diffusion of BVOCs from resin stores. Moreover, insect damage can break resin canals in needles, bark, and xylem and cause distinctive bursts of BVOCs during outbreaks. In the subarctic, mountain birch forests have cyclic outbreaks of Geometrid moths. During outbreaks, trees are often completely defoliated leading to an absence of BVOC-emitting foliage. However, in the years following an outbreak there is extended shoot growth, a greater number of leaves, and greater density of glandular trichomes that store BVOCs. This can lead to a delayed chemical defense response resulting in the highest BVOC emission rates from subarctic forest in the 1-3 years after an insect outbreak. Climate change is expected to increase insect outbreaks at high latitudes due to warmer seasons and arrivals of invasive herbivore species. Increased BVOC emission will affect tropospheric ozone $\left(\mathrm{O}_{3}\right)$ formation and $\mathrm{O}_{3}$ induced oxidation of BVOCs. Herbivore-induced BVOC emissions from deciduous and coniferous trees are also likely to increase the formation rate of SOA and further growth of the particles in the atmosphere. Field experiments measuring the BVOC emission rates, SOA formation rate and particle concentrations within and above the herbivore attacked forest stands are still urgently needed.
\end{abstract}

Keywords: drought; herbivory; secondary organic aerosols; volatile organic compounds; warming; boreal forest; subarctic

\section{Introduction}

Climate change effects on natural and man-made ecosystems are dominated by warming, which has resulted in global temperature increases of approximately $0.8^{\circ} \mathrm{C}$ since the 
late 19th century. During the same period, Arctic areas depending on measurement site have warmed by 2 to $3{ }^{\circ} \mathrm{C}$ [1]. At northern latitudes, the main drivers of rapid warming are increased ocean temperature that leads to decreased annual sea ice cover and reduced global albedo, and earlier terrestrial snow melt [2,3]. These drivers will affect other drivers of warming, such as increased emissions of the greenhouse gas methane from the oceans [3] and thawing permafrost [4-6]. Emissions of biogenic volatile organic compounds (BVOC) are strongly temperature dependent with daily and annual variation of emission rates [7]. Thus, warming in the boreal and subarctic areas will also increase the emission rates of BVOCs from soil and vegetation, peatlands [7,8], and lake waters [7]. In forests, the foliage [9], trunks [10], cones [11], roots, and rhizosphere [12,13] of trees, leaf and needle litter deposited on soil [14] and tree stumps [15] can be sources of BVOCs.

In polar areas and at high altitudes of mountainous areas, a cold temperature is the main factor limiting the diversity of organisms. However, climate warming, e.g., in the subarctic, might reduce species richness when the most cold-tolerant species face higher competition due to the spread of less-cold tolerant species [16]. In mountainous areas, larger plants, such as shrubs and trees, have shifted altitudinally upwards to former grasslands [17]. In northern forests, deciduous forest trees have shifted toward higher latitudes $[18,19]$.

Climate change with warming and consequential changes in precipitation will result in the shift of vegetational zones toward the north. These shifts include the expansion of woody shrubs into tundra ecosystems [20,21], a shift of the conifer boreal zone northwards to subarctic areas $[18,22,23]$, and an increased proportion of deciduous trees within the boreal conifer forest $[18,19]$. Insects are the major poikilothermic animal group to take advantage of a warming climate. There is already evidence that rapidly reproducing and invasive insect herbivores have become more common at northern latitudes and attack forest trees at higher rates causing serious outbreaks and forest decline in boreal conifer forests [24-26] and in subarctic deciduous forest [27,28].

According to a recent bibliometric analysis covering the years 1991 to 2018, a general trend in the BVOC literature has been for a growing focus on the assessment of plant stress responses and the atmospheric chemistry of BVOC emissions [29]. In this review we focus on the latest research on the emissions of non-methane BVOCs from boreal and subarctic forest trees under a changing climate. Our review also covers the effects of a warming climate on herbivore pressure and how this may affect the oxidation reactions of BVOCs in the atmosphere that lead to secondary organic aerosol (SOA) formation. Feedback loops between ecosystem change and atmospheric chemistry are still poorly known. The combination of ecological research and atmospheric chemistry research may provide explanations for BVOC-controlled biosphere-atmosphere interactions and lead to better tools for mitigation of ecological effects of global warming. A good example is from a recent study testing the effects of a defoliating moth outbreak on the atmospheric quality above a mountain birch forest [30]. On the basis of earlier laboratory experiments [31], it was expected that highly reactive herbivore-induced BVOC emissions may result in elevated SOA concentrations in the atmosphere. This was not the case, but the total aerosol particle concentrations were elevated for up to a few years after the infestation, which was expected to indicate delayed defense responses, such as the stimulated regrowth of mountain birch [30].

\section{Major BVOCs Emitted from Boreal and Subarctic Forest Ecosystems}

Boreal and subarctic forests are the most northern forest ecosystems before the arctic tundra. The major BVOCs found in these environments are the same low-molecularweight and mostly lipophilic volatile molecules that plants and microbes emit in a strongly temperature-dependent way in warmer ecosystems [32-34]. However, low- and semivolatile compounds might differ in their atmospheric and ecological behavior during the short and relatively cold summer. Semi-volatiles such as oxygenated sesquiterpenes become non-volatile and condense on plant surfaces during colder night temperatures 
before being re-emitted to the atmosphere from both the emitter plant and surfaces of neighbouring plants as temperatures warm the following day $[35,36]$.

The major chemical groups of BVOCs emitted by plants include terpenoids comprising the $\mathrm{C} 5$ isoprene and $\mathrm{C} 10$ monoterpenes synthesised by the 2-C-methyl-D-erythritol 4-phosphate (MEP) pathway in the plastids and C15 sesquiterpenes formed via the mevalonate pathway (MVA) in the cytosol, green leaf volatiles (GLV) formed via the oxylipin-lipoxygenase (LOX) pathway and aromatic compounds (benzenoids and phenylpropanoids) formed via the shikimate (SHI) pathway $[32,33,37]$. These compounds are effectively sampled with adsorbent-filled cartridges and analysed by gas chromatographymass spectrometry (GC-MS) in the laboratory [38]. Several studies have shown that the constitutive emission rates of these compounds from the foliage [9,37,39,40], bark [41,42], and root systems $[12,13,43]$ of trees are related to abiotic conditions. Many of these compounds are also emitted at an order of magnitude higher rates from herbivore or fungal pathogen-damaged plants [44-49]. Some of the compounds, such as GLVs and sesquiterpenes (SQT), are mostly detected in emissions after feeding damage [50]. High emissions of monoterpenes (MT) are typical of conifer forests and are released from stored and exposed resin. After insect feeding or mechanical damage, the resin flow from damaged needle stumps can release MTs at vastly higher rates than from intact twigs [10].

In recent years, studies using proton transfer reaction-mass spectrometry (PTR-MS) have indicated that forest trees can emit significant amounts of smaller, oxygenated volatile organic compounds (OVOC), which comprise non-methane $\mathrm{C} 1-\mathrm{C} 3$ molecules such as methanol, acetaldehyde, and acetone [42,51-55]. These emissions are related to changes in plant physiology and availability of water [42]. Emissions of highly volatile and water soluble OVOCs from stem bark indicate that OVOCs are leaked into the atmosphere when they are transported in the xylem sap from their sources in tree roots to the foliage [42,52]. Mechanical damage to foliage has been shown to significantly increase methanol and acetaldehyde emissions from leaves [51]. Emissions of herbivore-induced BVOCs are the result of a combination of mechanical plant tissue damage, together with insect secretions such as saliva and the enzymes therein [56]. The induction process of these BVOCs is described in more detail in Section 5. Structural examples of constitutively emitted (but abiotically controlled) BVOCs and herbivore-induced BVOC molecules are given in Figure 1.

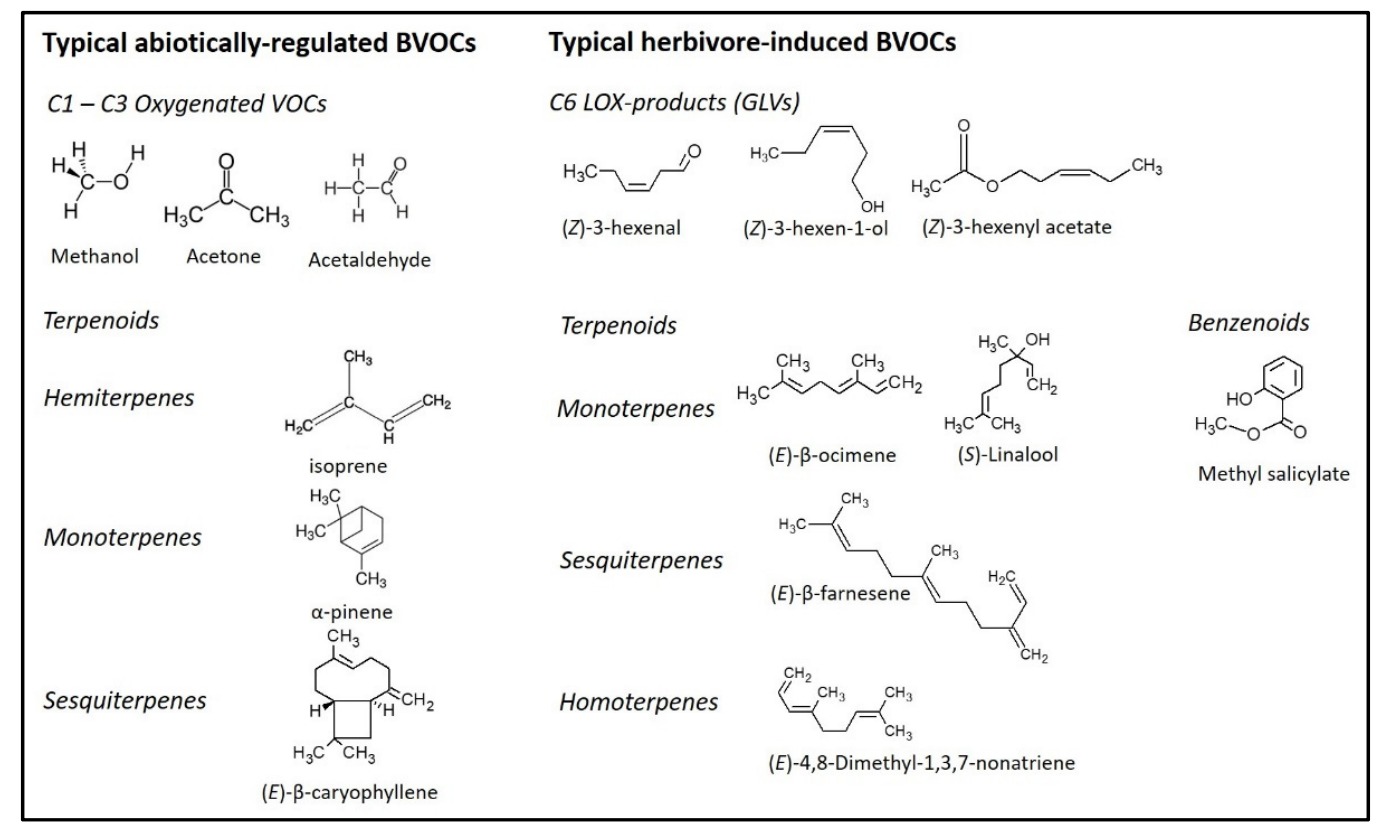

Figure 1. Examples of molecular structures of some major BVOCs emitted by boreal and subarctic forests trees. Constitutive BVOC emission rates are often regulated in response to abiotic factors such as temperature and light. Herbivore-induced BVOC emissions have strong response to herbivore feeding damage. 


\section{Effects of Warming and Light on BVOC Emissions from Trees and Rhizosphere}

Temperature is well known to play an important role in BVOC biosynthesis and emissions [57]. A rising temperature, up to approximately $40{ }^{\circ} \mathrm{C}$, can increase the activity of the enzymes involved in BVOC biosynthesis [58]. However, severe heat stress can result in cellular lesions and a reduction in photosynthesis that may not recover upon return to cooler temperatures, thus reducing de novo produced BVOC emissions [59]. Increasing temperatures may also increase the vaporization of BVOCs leaking from storage pools (ducts or glands) [60]. Therefore, temperature and light conditions during BVOC sampling have a substantial effect on calculated emission rates. As a consequence, the investigation of elevated temperature effects on plant emissions is complicated and longer-term climate warming effects should be separated from local weather condition effects during sampling. When the emission rates per unit of plant dry weight or leaf area are presented, they can be standardized to a certain target temperature, most commonly $30^{\circ} \mathrm{C}$ [57]. However, standardization steps should be carefully considered as they may not be suitable to colder regions that seldom reach temperatures as high as $30^{\circ} \mathrm{C}$ [61].

BVOC emissions are predicted to increase in response to long-term warming. To detect the effect of warming, plant BVOC emissions have been collected in experiments with plants grown in plots with either ambient temperatures or regulated warming with temperatures maintained at a target elevated level using heaters, e.g., modulated infra-red (IR) radiators $[62,63]$. The effects of warming on coniferous species have been investigated in Scots pine (Pinus sylvestris) and Norway spruce (Picea abies). In P. sylvestris, heating has been shown to have mixed results; an increase of $1{ }^{\circ} \mathrm{C}$ maintained with IR-heaters in an open-field has been shown to cause two-fold to four-fold increases in emissions of non-oxygenated monoterpenes (MT-no), oxygenated monoterpenes (MT-ox), and SQTs by seedlings [9]. However, in a study by Tiiva et al. [64] a greater warming increase $\left(2{ }^{\circ} \mathrm{C}\right.$ above the ambient level) showed unclear effects on BVOC emissions. In P. abies, warming $\left(1.3^{\circ} \mathrm{C}\right.$ above the ambient level) has been shown to increase emissions of MT-ox [65].

The effects of warming on BVOC emissions have also been studied in broad-leaved species. In European aspen (Populus tremula) saplings, an increase of $1{ }^{\circ} \mathrm{C}$ significantly increased emissions of total monoterpenes (MT) and green leaf volatiles (GLV) [62]. In a latter study, isoprene (IP) emission rate was shown to be increased by warming of $2{ }^{\circ} \mathrm{C}$ above the ambient level [66]. Studies on birch saplings (Betula pubescens var. pumila) also identified increased IP emissions in response to warming of $3-4{ }^{\circ} \mathrm{C}$ [67]. In a study of Betula pendula Roth an increase in emissions of mono- and homoterpenes, SQTs and compounds other than terpenes (GLVs and methyl salicylate (MeSA)) was observed with warming of $0.8-1{ }^{\circ} \mathrm{C}[68]$.

Warming affects BVOC emissions in different ways for different leaf types. In deciduous leaves without specific BVOC storage structures, emissions are affected by warming due to temperature-dependent biosynthesis. By comparison, BVOC emissions of conifer needles are affected by a combination of temperature-dependent biosynthesis and vaporization. Rhizosphere BVOC emissions can potentially be affected by warming via two main mechanisms; first they can be directly affected by environmental effects on the soil and roots, and secondly they can be indirectly affected, whereby emissions belowground are influenced by effects on the aboveground parts of the plant. The effects of warming on rhizosphere BVOC emissions have been investigated in a coniferous and a broadleaved boreal forest tree species. An elevated temperature of $1^{\circ} \mathrm{C}$ above the ambient level had only weak effects on $P$. sylvestris seedlings $[13,43]$. Moreover, warming had no effect on the emissions of $P$. tremula [66].

In the boreal forest zone, warming can alter the availability of water and nutrients and prolong the growing season [69], which is expected to alter the tree species composition. In Finland, the annual mean temperature in 2100 is predicted to be $4{ }^{\circ} \mathrm{C}$ higher than in 1990 [18]. By the same time, the countrywide proportions of P. sylvestris and P. abies are predicted to be reduced from 49 to $12 \%$ and from 38 to $33 \%$, respectively, with increased dominance of the birches B. pendula and Betula pubescens from 13 to 55\% [18]. The predicted 
changes in tree species composition, have been calculated to increase MT and IP emissions from 950 to $1108 \mathrm{~kg} \mathrm{~km}^{-2} \mathrm{y}^{-1}$ and from 132 to $214 \mathrm{~kg} \mathrm{~km}^{-2} \mathrm{y}^{-1}$, respectively [18]. However, predictions did not consider potential acclimation of tree species to warming, differences in responses to warming by different species (Table 1), or effects of increased herbivory under climate warming (see Sections 4-6).

Table 1. Examples of warming impacts on emissions of isoprene (IP), non-oxygenated monoterpenes (MT-no), oxygenated monoterpenes (MT-ox), monoterpenes (MT-no + MT-ox, MTs), sesquiterpenes (SQT), green leaf volatiles (GLV) and Methyl salicylate (MeSA). '+' shows the size of increasing warming effects; 'ne' means no warming effects.

\begin{tabular}{|c|c|c|c|c|}
\hline Tree Species & Warming Treatment & Responding Compounds & $\begin{array}{c}\text { Change in Temp. Standardized } \\
\text { Emission Rate }\end{array}$ & Reference \\
\hline \multirow{3}{*}{$\begin{array}{l}\text { Shoot } \\
\text { Pinus sylvestris }\end{array}$} & \multirow{3}{*}{ Ambient $+1{ }^{\circ} \mathrm{C}$} & & & \\
\hline & & MTs & $+200 \sim 400 \%$ & [9] \\
\hline & & SQTs & $+200 \sim 400 \%$ & [9] \\
\hline \multirow[t]{2}{*}{ Pinus sylvestris } & \multirow[t]{2}{*}{ Ambient $+2{ }^{\circ} \mathrm{C}$} & $\hat{\mathrm{MTs}}$ & ne & [64] \\
\hline & & SQTs & Only found in warming & [64] \\
\hline \multirow[t]{4}{*}{ Picea abies } & \multirow[t]{4}{*}{ Ambient $+1.3{ }^{\circ} \mathrm{C}$} & IP & ne & [65] \\
\hline & & MT-ox & PCA result: + & {$[65]$} \\
\hline & & MTs & ne & {$[65]$} \\
\hline & & SQTs & ne & {$[65]$} \\
\hline \multirow{3}{*}{ Populus tremula } & \multirow{3}{*}{ Ambient $+1{ }^{\circ} \mathrm{C}$} & IP & ne & {$[62]$} \\
\hline & & MTs & $+300 \%$ & [62] \\
\hline & & GLVs & $+400 \%$ & [62] \\
\hline \multirow[t]{4}{*}{ Populus tremula } & \multirow[t]{4}{*}{ Ambient $+2{ }^{\circ} \mathrm{C}$} & IP & $+56 \%$ & {$[66]$} \\
\hline & & MTs & ne & {$[66]$} \\
\hline & & SQTs & ne & [66] \\
\hline & & GLVs & ne & {$[66]$} \\
\hline \multirow[t]{3}{*}{ Betula pendula Roth } & \multirow[t]{3}{*}{$\begin{array}{c}\text { Ambient } \\
+0.8 \sim 1{ }^{\circ} \mathrm{C}\end{array}$} & MTs + homoterpenes & $+400 \%$ & [68] \\
\hline & & SQTs & $+400 \%$ & [68] \\
\hline & & GLVs + MeSA & $+40 \%$ & [68] \\
\hline $\begin{array}{l}\text { Betula pubescens } \\
\text { var. pumila }\end{array}$ & $\begin{array}{l}\text { Ambient } \\
+3 \sim 4{ }^{\circ} \mathrm{C}\end{array}$ & $\mathrm{IP}$ & $+70 \%$ & [67] \\
\hline Rhizosphere & & & & \\
\hline Pinus sylvestris & Ambient $+1^{\circ} \mathrm{C}$ & MTs & ne & [13] \\
\hline Pinus sylvestris & Ambient $+1^{\circ} \mathrm{C}$ & MTs & ne & [43] \\
\hline Populus tremula & Ambient $+1^{\circ} \mathrm{C}$ & IP & ne & {$[66]$} \\
\hline
\end{tabular}

Examples of tree species distributions moving northwards from boreal forests toward the subarctic and arctic tundra include the larch species of North America [70] and Siberia [71]. Siberian larch (Larix sibirica) and Dahurican larch (Larix dahurica) are dominant tree species in the large Siberian boreal forest ecoregion known as the Taiga [71,72]. BVOC emissions of these two larch species consist of approximately $90 \%$ monoterpenes, with the remainder including sesquiterpenes that could account for up to $10 \%$ of the total emission in summer time [72]. The American larch (Larix laricina) is a tree line species in the boreal forest of Canada [70] and also has a high monoterpene content [73]. Thus, in future, larch species have the potential to become significant monoterpene and sesquiterpene emitters in the current arctic and subarctic tundra area.

\section{Effects of Climate Warming on Density and Distribution of Herbivores}

Many tree-damaging forest insects have a cycle of several years between reaching their outbreak population densities (pest status) within their natural geographical ranges. This cyclicity is linked to variation in the top-down control (by natural enemies) and bottom-up control (by resource limitation and host plant quality) $[74,75]$. Annual variation in weather conditions will affect these controlling factors, but the weather also directly influences the physiology and propagation rate of herbivorous insects [76]. Increases in mean temperature 
because of climate warming affect the warming-induced distribution shift of forest insects towards high latitudes [24,26] and high altitudes [76]. Thus, in the future, a higher risk of insect outbreaks in boreal and subarctic forests will come from more frequent outbreaks of native species and additional outbreaks by invasive exotic forest insects.

Some of the major outbreak species of boreal and subarctic forests have become more common because of climate warming (Table 2). Some species are already native outbreak species that only occasionally reach outbreak levels in the cooler climate, for example the bark beetle Ips typographus [77] and the sawfly Neodiprion sertifer [78]. Other species such as Lymantria monacha and Lymantria dispar are invasive, e.g., in the boreal zone of Finland, and their population densities may reach outbreak levels in the future [24].

Table 2. Some major defoliating and bark/trunk damaging outbreak species of boreal trees and species showing expansion towards the north under climate warming to date. Damage type; $\mathrm{D}=$ defoliator, $\mathrm{T}=$ trunk and bark damage.

\begin{tabular}{|c|c|c|c|}
\hline Herbivore Species & Damage Type & Host Tree Species & References \\
\hline European pine sawfly, Neodiprion sertifer, Geoffrey & $\mathrm{D}$ & Scots pine, Pinus sylvestris L. & [78] \\
\hline Autumnal moth, Epirrita autumnata, Bork. & $\mathrm{D}$ & $\begin{array}{l}\text { Mountain Birch, Betula pubescens var. } \\
\text { pumila, (N. I. Orlova) Hämet-Ahti }\end{array}$ & [79] \\
\hline Winter moth, Operophtera brumata, L. & $\mathrm{D}$ & $\begin{array}{l}\text { Mountain birch, B. pubescens var. pumila, } \\
\text { (N. I. Orlova) Hämet-Ahti }\end{array}$ & [80] \\
\hline Ips typographus & $\mathrm{T}$ & Norway spruce, Picea abies, Karst. & [26] \\
\hline Siberian silkmoth, Dendrolimus sibiricus Tschetv. & $\mathrm{D}$ & $\begin{array}{c}\text { Several conifer species, Abies, Larix, Picea } \\
\text { and Pinus spp. }\end{array}$ & {$[81,82]$} \\
\hline Nun moth, Lymantria monacha L. & $\mathrm{D}$ & Mainly on conifers & [24] \\
\hline Gypsy moth (L. dispar L.) & $\mathrm{D}$ & Mainly on deciduous trees & [24] \\
\hline $\begin{array}{c}\text { Great web-spinning pine-sawfly Acantholyda } \\
\text { posticalis Mats }\end{array}$ & $\mathrm{D}$ & Scots pine, P. sylvestris L. & [83] \\
\hline $\begin{array}{c}\text { Mountain pine beetle, Dendroctonus } \\
\text { ponderosae, Hopkins }\end{array}$ & $\mathrm{T}$ & Pines, Pinus spp. & [84] \\
\hline
\end{tabular}

I. typographus attacks are predicted to increase on P. abies [26], with increased effective temperature sums coinciding with more favorable conditions for swarming. Areas with favorable temperature sums for the complete development of bivoltine populations of I. typographus (>1500 degree days (DD)) shifted northwards by an average of $450 \mathrm{~km}$ during the entire study period of 1960-2016 [26]. Massive 2.5 M ha outbreaks of the Siberian silk moth Dendrolimus sibiricus have shifted northward by up to $500 \mathrm{~km}$ in the Siberian boreal conifer forest during the last 40 years with the shift promoted by droughts and an increase in the temperature sum $[81,82]$. Higher winter temperatures and decreased summer precipitation are the main drivers of the range expansion of Mountain pine beetle, Dendroctonus ponderosae, towards the north in the USA and Canada [84,85]. Major defoliator species that exhibit a warming-related distribution shift towards the north in European Boreal forest include the Nun moth (L. monacha) and the Gypsy moth (L. dispar) [24]. Higher winter survival of eggs and improved dispersal and reproduction success of adult moths are the main drivers for the northward distribution of L. monacha [25]. The critical temperature for survival of L. monacha eggs in tree bark cracks is $-29.5^{\circ} \mathrm{C}$. On the southwestern coast of Finland, temperatures have not dropped below this lethal limit since the year 1987 [25].

$N$. sertifer overwinters as eggs deposited in pine needles. Winter temperatures below $-35^{\circ} \mathrm{C}$ limit egg survival leading to larger larval populations and an increase in outbreak potential after mild winters [78]. The great web-spinning pine-sawfly Acantholyda posticalis overwinters as a larva in soil and in recent years more frequent outbreaks have occurred in pine forests of milder coastal areas of the Baltic sea [83].

\section{Herbivore Feeding and Oviposition Effects on BVOC Emissions}

The percentage of the boreal forest area affected by biotic stress annually was calculated to average $4 \%$ between 1988 and 2013 [86]. Insect herbivory contributed most to the total observed damage [86]. Feeding or oviposition by herbivores leads to mechanical dam- 
age of plant cells including structural degradation of membranes. Chewing and sucking feeding modes, oviposition, and oral and ovipositor secretions elicit a signal transduction cascade that activates transcription factors of the WRKY gene family [87-89]. These transcription factors control phytohormones (salicylic acid, jasmonic acid, and ethylene) that elicit the production of herbivore-induced BVOCs [87]. In terpene storing species such as conifers, herbivore feeding damage promotes release of constitutively emitted BVOCs, such as monoterpenes that have a several fold increase in emission rate after damage by leaf chewing herbivores $[9,10,90]$. Herbivore damage to plants has also been shown to increase emissions of GLVs and methyl salicylate (MeSA). The effects of herbivore-feeding on BVOC emissions can vary dramatically depending on the mode of feeding and the part of the plant that is fed upon. In the following paragraphs we detail some of the key plant responses to herbivore-feeding and the effects of herbivores with different feeding strategies (Table 3 ).

Table 3. Examples of insect herbivory impacts on emissions of non-oxygenated monoterpenes (MT-no), oxygenated monoterpenes (MT-ox), monoterpenes (MT-no + MT-ox, MTs), sesquiterpenes (SQT), green leaf volatiles (GLV) and Methyl salicylate (MeSA). '+' shows the size of increasing warming effects; 'ne' means no warming effects.

\begin{tabular}{|c|c|c|c|c|}
\hline Tree Species & Herbivory & Responding Compounds & $\begin{array}{l}\text { Change in Temp. Standardized } \\
\text { Emission Rate }\end{array}$ & Reference \\
\hline \multicolumn{5}{|l|}{ Shoot } \\
\hline \multicolumn{5}{|c|}{ Bark Damaging Herbivore-Feeding/Conifer and Broadleaf Tree Systems } \\
\hline \multirow[t]{2}{*}{$\begin{array}{c}\text { Scots pine } \\
\text { Pinus sylvestris }\end{array}$} & $\begin{array}{l}\text { Large pine weevil } \\
\text { Hylobius abietis }\end{array}$ & MTs & $+280 \sim 400 \%$ & [44] \\
\hline & & SQTs & $+290 \sim 700 \%$ & [44] \\
\hline \multirow[t]{2}{*}{$\begin{array}{c}\text { Scots pine } \\
\text { Pinus sylvestris }\end{array}$} & $\begin{array}{l}\text { Large pine weevil } \\
\text { Hylobius abietis }\end{array}$ & MTs & $+1697 \%$ & [91] \\
\hline & & SQTs & $+357 \%$ & [91] \\
\hline \multirow[t]{2}{*}{$\begin{array}{c}\text { Scots pine } \\
\text { Pinus sylvestris }\end{array}$} & $\begin{array}{l}\text { Large pine weevil } \\
\text { Hylobius abietis }\end{array}$ & MTs & $+4224 \%$ & [92] \\
\hline & & GLVs & $+114 \%$ & [92] \\
\hline \multirow[t]{2}{*}{$\begin{array}{c}\text { Scots pine } \\
\text { Pinus sylvestris }\end{array}$} & $\begin{array}{l}\text { Large pine weevil } \\
\text { Hylobius abietis }\end{array}$ & MTs & ne & [64] \\
\hline & & GLVs & ne & [64] \\
\hline $\begin{array}{c}\text { Scots pine } \\
\text { Pinus sylvestris }\end{array}$ & $\begin{array}{l}\text { Large pine weevil } \\
\text { Hylobius abietis }\end{array}$ & MTs & $+9000 \%$ & [93] \\
\hline \multirow[t]{2}{*}{$\begin{array}{c}\text { Scots pine } \\
\text { Pinus sylvestris }\end{array}$} & $\begin{array}{l}\text { Large pine weevil } \\
\text { Hylobius abietis }\end{array}$ & MTs & $+300 \%$ & [94] \\
\hline & & SQTs & $+800 \%$ & [94] \\
\hline \multirow[t]{2}{*}{$\begin{array}{c}\text { Norway spruce } \\
\text { Picea abies }\end{array}$} & $\begin{array}{l}\text { Large pine weevil } \\
\text { Hylobius abietis }\end{array}$ & MTs & $+1078 \%$ & [91] \\
\hline & & SQTs & $+7300 \%$ & [91] \\
\hline \multirow[t]{3}{*}{$\begin{array}{c}\text { Norway spruce } \\
\text { Picea abies }\end{array}$} & $\begin{array}{l}\text { Large pine weevil } \\
\text { Hylobius abietis }\end{array}$ & MTs & +97 744\% & [95] \\
\hline & & GLVs & ne & [95] \\
\hline & & SQTs & $+4355 \sim 5471 \%$ & [95] \\
\hline $\begin{array}{c}\text { Norway spruce } \\
\text { Picea abies }\end{array}$ & $\begin{array}{l}\text { Spruce bark beetle } \\
\text { Ips typographus }\end{array}$ & MTs & $+2000 \%$ & [96] \\
\hline
\end{tabular}


Table 3. Cont.

\begin{tabular}{|c|c|c|c|c|}
\hline Tree Species & Herbivory & Responding Compounds & $\begin{array}{c}\text { Change in Temp. Standardized } \\
\text { Emission Rate }\end{array}$ & Reference \\
\hline & & SQTs & ne & [96] \\
\hline \multirow[t]{2}{*}{$\begin{array}{l}\text { Sitka spruce } \\
\text { Picea sitchensis }\end{array}$} & $\begin{array}{l}\text { Pine weevils } \\
\text { Pissodes strobi }\end{array}$ & MTs & $+650 \%$ & [97] \\
\hline & & SQTs & $+1190 \%$ & [97] \\
\hline $\begin{array}{l}\text { Mountain pine beetle }\left(^{*}\right) \\
\text { Dendroctonus ponderosae }\end{array}$ & $\begin{array}{l}\text { Lodgepole pine } \\
\text { Pinus contorta }\end{array}$ & MTs & $+12,000 \%$ & [98] \\
\hline $\begin{array}{l}\text { Mountain pine beetle }(*) \\
\text { Dendroctonus ponderosae }\end{array}$ & $\begin{array}{c}\text { Jack pine } \\
\text { Pinus banksiana }\end{array}$ & MTs & $+350 \%$ & [98] \\
\hline \multirow[t]{3}{*}{$\begin{array}{c}\text { Silver birch } \\
\text { Betula pendula Roth }\end{array}$} & $\begin{array}{l}\text { Large pine weevil } \\
\text { Hylobius abietis }\end{array}$ & MTs & ne & {$[50]$} \\
\hline & & SQTs & ne & {$[50]$} \\
\hline & & GLVs & ne & {$[50]$} \\
\hline \multicolumn{5}{|c|}{ Foliage Damaging Herbivore-Feeding/Conifer and Broadleaf Tree Systems } \\
\hline \multirow[t]{4}{*}{$\begin{array}{c}\text { Scots pine } \\
\text { Pinus sylvestris }\end{array}$} & $\begin{array}{c}\text { Pine sawfly } \\
\text { Neodiprion sertifer }\end{array}$ & MTs & $+981 \%$ & [91] \\
\hline & & SQTs & $+988 \%$ & [91] \\
\hline & & GLVs & $+487 \%$ & [91] \\
\hline & & MeSA & $+500 \%$ & [91] \\
\hline \multirow[t]{3}{*}{$\begin{array}{c}\text { Scots pine } \\
\text { Pinus sylvestris }\end{array}$} & $\begin{array}{l}\text { Pine sawfly } \\
\text { Neodiprion sertifer }\end{array}$ & MTs & $+1400 \%$ & [10] \\
\hline & & SQTs & $+700 \%$ & [10] \\
\hline & & GLVs & $+1300 \%$ & [10] \\
\hline \multirow[t]{4}{*}{$\begin{array}{l}\text { Scots pine } \\
\text { Pinus sylvestris }\end{array}$} & $\begin{array}{l}\text { Pine sawfly } \\
\text { Acantholyda } \\
\text { posticalis }\end{array}$ & MT-no & $+550 \sim 2100 \%$ & [40] \\
\hline & & MT-ox & $+0 \sim 910 \%$ & [40] \\
\hline & & SQTs & $+560 \sim 1100 \%$ & [40] \\
\hline & & GLVs & $+650 \sim 920 \%$ & {$[40]$} \\
\hline \multirow[t]{2}{*}{$\begin{array}{l}\text { Scots pine } \\
\text { Pinus sylvestris }\end{array}$} & $\begin{array}{l}\text { Pine sawfly } \\
\text { Acantholyda } \\
\text { posticalis }\end{array}$ & MTs & ne & [9] \\
\hline & & SQTs & $+300 \%$ & [9] \\
\hline $\begin{array}{l}\text { Norway spruce } \\
\text { Picea abies }\end{array}$ & $\begin{array}{l}\text { Needle-eating } \\
\text { weevils } \\
\text { Strophosoma } \\
\text { melanogrammum }\end{array}$ & MTs & $+300 \sim 2000 \%$ & [99] \\
\hline \multirow[t]{3}{*}{$\begin{array}{l}\text { Mountain birches } \\
\text { Betula pubescens var. pumila }\end{array}$} & $\begin{array}{l}\text { Autumnal moth } \\
\text { Epirrita autumnata }\end{array}$ & MTs & $+470 \%$ & [100] \\
\hline & & SQTs & $+117 \%$ & [100] \\
\hline & & GLVs & $+195 \%$ & [100] \\
\hline \multirow[t]{2}{*}{$\begin{array}{c}\text { Mountain birch } \\
\text { Betula pubescens var. pumila }\end{array}$} & $\begin{array}{l}\text { Autumnal moth } \\
\text { Epirrita autumnata }\end{array}$ & MTs & $+1000 \%$ & {$[31]$} \\
\hline & & SQTs & $+200 \%$ & [31] \\
\hline
\end{tabular}


Table 3. Cont.

\begin{tabular}{|c|c|c|c|c|}
\hline Tree Species & Herbivory & Responding Compounds & $\begin{array}{c}\text { Change in Temp. Standardized } \\
\text { Emission Rate }\end{array}$ & Reference \\
\hline & & GLV & $+800 \%$ & [31] \\
\hline \multirow[t]{3}{*}{$\begin{array}{l}\text { Mountain birch } \\
\text { Betula pubescens var. pumila }\end{array}$} & $\begin{array}{l}\text { Autumnal and } \\
\text { winter moth } \\
\text { Epirrita autumnata } \\
\text { and Operophtera } \\
\text { brumata }\end{array}$ & MTs & $+200 \sim 5200 \%$ & [101] \\
\hline & & SQTs & $-30 \sim+500 \%$ & [101] \\
\hline & & GLV & $-70 \sim+3050 \%$ & [101] \\
\hline \multirow[t]{2}{*}{$\begin{array}{l}\text { Silver birch } \\
\text { Betula pendula Roth } \\
\text { (clones } 4 \text { and } 80 \text { ) }\end{array}$} & $\begin{array}{l}\text { Autumnal moth } \\
\text { Epirrita autumnata }\end{array}$ & MTs & $+1100 \%$ & [102] \\
\hline & & SQTs & $+140 \%$ & [102] \\
\hline \multirow[t]{3}{*}{$\begin{array}{c}\text { Hybrid aspen } \\
\text { Populus tremula } \mathrm{L} . \times P \text {. } \\
\text { tremuloides Michx. }\end{array}$} & $\begin{array}{l}\text { Autumnal moth } \\
\text { Epirrita autumnata }\end{array}$ & MTs & $+385 \%$ & [103] \\
\hline & & SQT & $+505 \%$ & [103] \\
\hline & & GLV & $+1157 \%$ & [103] \\
\hline \multirow[t]{2}{*}{$\begin{array}{c}\text { Hybrid aspen } \\
\text { Populus tremula L. } \times P \text {. } \\
\text { tremuloides Michx (Clone } \\
\text { 55) }\end{array}$} & $\begin{array}{l}\text { Autumnal moth } \\
\text { Epirrita autumnata }\end{array}$ & MTs & $+\%$ & [104] \\
\hline & & SQTs & $+422 \%$ & [104] \\
\hline $\begin{array}{c}\text { Hybrid aspen } \\
\text { Populus tremula L. } \times \text { P. } \\
\text { tremuloides Michx (Clone } \\
100)\end{array}$ & $\begin{array}{l}\text { Autumnal moth } \\
\text { Epirrita autumnata }\end{array}$ & SQTs & $+570 \%$ & [104] \\
\hline $\begin{array}{l}\text { Silver birch } \\
\text { Betula pendula Roth }\end{array}$ & $\begin{array}{l}\text { Geometrid moth } \\
\text { Erannis defoliaria } \\
\text { Hübner }\end{array}$ & GLVs & $+900 \%$ & [50] \\
\hline \multirow[t]{3}{*}{$\begin{array}{c}\text { Black alder } \\
\text { Alnus glutinosa }\end{array}$} & $\begin{array}{l}\text { Geometrid moth } \\
\text { Cabera pusaria }\end{array}$ & MTs & $+940 \%$ & [105] \\
\hline & & SQTs & $+200 \%$ & [105] \\
\hline & & GLV & $+2000 \%$ & [105] \\
\hline \multicolumn{5}{|c|}{ Piercing-Sucking Herbivore-Feeding/Conifer and Broadleaf Tree Systems } \\
\hline \multirow[t]{3}{*}{$\begin{array}{c}\text { Scots pine } \\
\text { Pinus sylvestris }\end{array}$} & $\begin{array}{l}\text { Large pine aphid } \\
\text { Cinara pinea } \\
\text { Mordvilko }\end{array}$ & MTs & ne & [106] \\
\hline & & SQTs & $+582 \%$ & [106] \\
\hline & & MeSA & $+7413 \%$ & [106] \\
\hline $\begin{array}{c}\text { Silver birch } \\
\text { Betula pendula (Roth) }\end{array}$ & $\begin{array}{c}\text { Aphid } \\
\text { Euceraphis betulae } \\
\text { (Koch.) }\end{array}$ & MeSA & $+319 \sim 1526 \%$ & [107] \\
\hline $\begin{array}{c}\text { Black alder } \\
\text { Alnus glutinosa (L.) } \\
\text { (Gaertn.) }\end{array}$ & $\begin{array}{c}\text { Aphid } \\
\text { Pterocallis alni } \\
\text { (DeGeer) }\end{array}$ & MeSA & $+9826 \%$ & [107] \\
\hline
\end{tabular}


Table 3. Cont.

\begin{tabular}{|c|c|c|c|c|}
\hline Tree Species & Herbivory & Responding Compounds & $\begin{array}{c}\text { Change in Temp. Standardized } \\
\text { Emission Rate }\end{array}$ & Reference \\
\hline \multicolumn{5}{|l|}{ Rhizosphere } \\
\hline \multirow[t]{2}{*}{$\begin{array}{c}\text { Scots pine } \\
\text { Pinus sylvestris }\end{array}$} & $\begin{array}{c}\text { Pine sawfly } \\
\text { Neodiprion sertifer }\end{array}$ & MTs & $-80 \%$ & [10] \\
\hline & & SQTs & ne & [10] \\
\hline $\begin{array}{l}\text { Scots pine } \\
\text { Pinus sylvestris }\end{array}$ & $\begin{array}{l}\text { Pine sawfly } \\
\text { Acantholyda } \\
\text { posticalis }\end{array}$ & MTs & ne & [13] \\
\hline $\begin{array}{c}\text { Scots pine } \\
\text { Pinus sylvestris }\end{array}$ & $\begin{array}{l}\text { Large pine weevil } \\
\text { Hylobius abietis }\end{array}$ & MTs & ne & [43] \\
\hline \multirow[t]{2}{*}{$\begin{array}{c}\text { Silver birch } \\
\text { Betula pendula Roth }\end{array}$} & $\begin{array}{l}\text { Large pine weevil } \\
\text { Hylobius abietis }\end{array}$ & MTs & ne & [50] \\
\hline & $\begin{array}{l}\text { Geometrid moths } \\
\text { Agriopis aurantiaria } \\
\text { (Clerck) and } \\
\text { Erannis defoliaria } \\
\text { Hübner }\end{array}$ & MTs & ne & [50] \\
\hline \multicolumn{5}{|c|}{ Oviposition/Conifer Tree Systems } \\
\hline $\begin{array}{c}\text { Scots pine } \\
\text { Pinus sylvestris }\end{array}$ & $\begin{array}{c}\text { Sawfly } \\
\text { Diprion pini }\end{array}$ & MTs & $+6 \%$ & [108] \\
\hline
\end{tabular}

$\left({ }^{*}\right)=$ induction by bark beetle associated fungi.

Bark-feeding herbivores are among the most damaging outbreak pests of boreal forests. The large pine weevil (Hylobius abietis) is a pest of conifers such as P. sylvestris [109]. Several studies have shown that $H$. abietis damage on the stem bark of $P$. sylvestris can cause an increase in both localized and systemic emissions of BVOC, including MTs, SQTs, and GLVs that can increase several-fold after feeding [44,91-94]. The increase in localized BVOC emissions is mainly due to passive evaporation of compounds from resin accumulated at stem feeding sites [97]. The increased systemic BVOC emissions could have several different explanations, including: (1) BVOC synthesis elicited by a signal transmitted via vascular tissue; (2) BVOC synthesis elicited by a signal transmitted via airborne signals from the damage-site to the foliage; and (3) leakage of BVOCs from branch bark where the wounding increases resin flow from foliage via resin ducts [44]. In addition, BVOCs emitted from damage sites may be adsorbed to and then re-emitted from needle surfaces. H. abietis feeding has also been shown to increase BVOC emissions have in P. abies [91,95]. However, the most severe pest of $P$. abies throughout Europe is Ips typographus, an aggressive beetle species. In a study by Ghimire et al. [96], I. typographus attack increased MT emissions from the bark surface by 20 -fold. In western North America, the white pine weevil (Pissodes strobi) is the most destructive insect pest of Sitka spruce (Picea sitchensis) [110]. Feeding by P. strobi on bark induces a rapid release of MTs and SQTs from P. sitchensis [97]. Bark-feeding herbivores can also induce BVOC emissions indirectly, e.g., the mountain pine beetle (Dendroctonus ponderosae) associated fungus Grosmannia clavigera substantially increased MT emissions in Pinus contorta and Pinus banksiana [98]. Bark damaging herbivores also feed on broad-leaved species. H. abietis, for example, has been reported to feed on silver birch (Betula pendula) bark, but did not affect the BVOC emissions of shoots [50].

Defoliating insects are also major outbreak pests in the boreal and subarctic region. Defoliating pests of conifers, such as the sawflies Neodiprion sertifer [10,91] and Acantholyda posticalis $[9,40]$, have been shown to induce shoot BVOC emissions during needle-feeding. The needle-feeding weevil, Strophosoma melanogrammum, was also found to enhance shoot MT emissions from P. abies [99]. The increased BVOC emissions from herbivore-damaged conifer shoots may have resulted from emission bursts caused by the breakage of needle 
resin canals during the herbivore attack. Defoliating insects can also cause substantial damage to broadleaved plants. Feeding by the autumnal moth, Epirrita autumnata, has been shown to increase shoot BVOC emissions from mountain birch [31,100,101], silver birch [102], and hybrid aspen [103,104]. Shoot BVOC emissions were also found to increase in response to feeding damage by Erranis defoliaria in silver birch [50] and Cabera pusaria in alder (Alnus glutinosa) [105]. Herbivore-induced BVOC emissions might be used as a defense against herbivory. For example, there is evidence that aspen produce volatile chemicals upon herbivore damage that attract predators and parasitoids [111-113].

It is notable that while not constituting as important pests as outbreaking bark beetles and defoliating insects, piercing-sucking herbivores also infest trees in the boreal and subarctic regions, and have effects on BVOC emissions. Although there have been numerous studies on plants in general [114], very few studies have explicitly investigated the effects of piercing-sucking herbivores on BVOC emissions of boreal trees. Kivimäenpää et al. [106] showed that $P$. sylvestris infested by the aphid Cinara pinea Mordvilko, had significantly increased emissions of methyl salicylate (MeSA) and SQTs, but MT emissions were not affected. In a study of B. pendula and A. glutinosa by Blande et al. [107], some induced terpene emissions were recorded, but the most notable aphid-induced emission was MeSA. These two studies indicate that aphid-feeding characteristically induces emissions of MeSA which appear to be dependent on aphid density [106] and duration of infestation [107].

While the BVOC emissions of aboveground plant parts have typically received greater attention than those emitted belowground, we found four studies addressing the effects of herbivore-feeding on BVOC emissions from the rhizosphere [10,13,43,50]. Leaf feeding by the geometrid moth species E. defoliaria Clerck and Agriopis aurantiaria Hübner and bark feeding by $H$. abietis had no effect on rhizosphere BVOC emissions from B. pendula [50]. Moreover, needle [13] and bark [43] feeding on P. sylvestris had no clear effects on BVOC emissions from the rhizosphere. Assessment of herbivore-feeding directly on roots appears to be lacking from the current literature.

In addition to herbivore feeding, oviposition by herbivores can induce BVOC emissions in boreal forest tree species [108]. Oviposition on P. sylvestris by the sawfly Diprion pini was shown to increase production of MTs [108]. Plant responses to oviposition can directly affect the eggs. Emission of benzyl benzoate, for example, can have an active ovicidal function [115]. Oviposition-induced BVOC emissions can also structure defenses against neonate larvae; for instance, oviposition by the moth species Chilo partellus has been shown to attract the larval parasitoid Cotesia sesamiae [116]. Likewise, oviposition by the large cabbage white butterfly (Pieris brassicae) on the wild crucifer Brassica nigra attracted the larval parasitoid Cotesia glomerata [117]. In P. sylvestris, BVOC emissions induced by D. pini oviposition attract the egg parasitoid Chrysonotomyia ruforum [108]. However, more studies are needed to investigate BVOC emission responses to oviposition by herbivores in boreal trees.

In general, BVOC emissions from boreal trees were increased by herbivore stress. However, in a natural environment, herbivore stress does not occur in isolation. Trees are exposed to multiple concurrent biotic and abiotic stressors. To date there are few studies on how herbivore-induced BVOC emissions in boreal and subarctic forests are affected by simultaneous abiotic stresses, including potential modifications in a warming climate.

\section{Combined Warming and Herbivore-Feeding Effects on BVOC Emissions}

In the previous section, several examples of herbivore-feeding effects on BVOC emissions were presented. The effects of insect herbivore feeding on BVOC emissions depend on various internal plant and environmental factors [118]. Temperature is the most important abiotic driver of BVOC emissions; it affects the chemical defense strategies of plants and thus influences the capacity of plants to emit BVOCs. An analysis of 18 terpene-storing Pinus spp. from altitudinal and latitudinal gradients indicated that species originating from colder high altitudes rely more on constitutive defenses (terpenes produced in storage structures), while species originating from warmer environments rely more on induced 
defenses (terpenes synthesized after induction by tissue damage) [119]. This may suggest that in warming climatic conditions conifers adapted to cold conditions could become more active producers of induced BVOCs under herbivore attack. Over a longer time frame, the result of a warming climate could be that conifer species and provenances that have stronger induced defense response will prevail in boreal and subarctic forests.

The biotic stress and damage caused by herbivores is strongly influenced by the feeding habits and mode of the herbivore such as chewing, sucking, mining, or gall forming strategies. Host plant responses to these specific damage types is influenced by abiotic conditions during damage, which together influence the dominant BVOC composition in the specific global vegetational zone [120]. For example, isoprene is a major BVOC released by vegetation at latitudes closest to the equator while at higher latitudes monoterpenes are the more dominant BVOC emissions $[120,121]$. An analysis of the effects of gall-forming insect feeding on plant emissions in low and high latitude vegetation zones indicated a general trend for feeding damage to reduce isoprene emission rates with the relative reduction most distinctive at low latitudes. Monoterpene emissions responded positively to gall-forming insect feeding with the relative change at the same level as for isoprene, but in the opposite direction. The highest increase and relative change were detected for sesquiterpene emissions in tropical areas, while GLVs were emitted by all infected leaves in all regions [120].

The effects of a combination of warming and herbivore pressure on BVOC emissions are most naturally studied in experimental field exposure systems where plants are grown in plots with either ambient conditions or a warming treatment that elevates temperature to a target level. In warming plots, infrared radiators are used to continually expose the canopy to an elevated target temperature for $24 \mathrm{~h}$ per day. Limitations in these systems are that most of the studies are conducted using small tree seedlings or saplings. Another approach is to build a closed top [122] or open-top chamber over a single tree and control the temperature inside the chamber and compare chamber-enclosed trees at various temperatures. Investigations of herbivory effects on tree BVOC emissions under these conditions are difficult and there is a risk of unintentional insect outbreaks by typical greenhouse pest insects such as aphids. Closed chamber experiments are more easily regulated for temperature and confounding factors, but are less natural.

In an open-field exposure system with Scots pine seedlings, modest feeding damage $(10 \%$ of a shoot) by larvae of the sawfly A. posticalis in combination with warming $\left(+1{ }^{\circ} \mathrm{C}\right.$ addition) did not affect BVOC emissions of Scots pine during the growing season, although both factors separately increased emissions [9]. Substantially elevated monoterpene emissions from warming treatments, where needles developed larger resin canals, were partly masking potential interactive effects [9]. However, in the same study, warming and herbivory from the previous growing season increased emissions of the monoterpene camphene at the beginning of the next growing season, highlighting the potential long-term effects of herbivory under climate warming. Warming can also cause thermal stress to herbivores [123] and a $1{ }^{\circ} \mathrm{C}$ warming lasting three growing seasons was shown to reduce feeding by A. posticalis and herbivory-induced total MT emissions by 77\% [40]. A closed chamber experiment by Tiiva et al. [64] showed that a $+2{ }^{\circ} \mathrm{C}$ temperature increase and short-term bark herbivory by $\mathrm{H}$. abietis increased total MT emissions from foliage of Scots pine seedling growing in $\mathrm{N}$-fertilized ( $30 \mathrm{~kg} \mathrm{ha}^{-1}$ year $^{-1}$ ) soil.

An open field experiment using needle-feeding $A$. posticalis larvae reduced emissions of minor MTs from the rhizosphere where roots were the main emission source, while warming $\left(1{ }^{\circ} \mathrm{C}\right.$ in air and $0.7^{\circ} \mathrm{C}$ in soil) did not influence the emission response [13]. Another open field experiment examining responses to $H$. abietis weevils showed reductions in emissions of total sesquiterpenes and total non-terpenoid volatiles from the roots in response to herbivory, while warming $\left(0.5^{\circ} \mathrm{C}\right.$ in air and $4{ }^{\circ} \mathrm{C}$ in soil) reduced emissions of monoterpenes, sesquiterpenes, and total non-terpenoid volatiles [124]. The reductions were not observed when warming and herbivory were combined. In a closed chamber experiment, a short feeding period by $\mathrm{H}$. abietis weevils on the bark at the base of the stem 
reduced some root $\mathrm{BVOC}$ emissions, but this reduction was not evident in a $+2{ }^{\circ} \mathrm{C}$ warming treatment [43]. Thus, herbivory effects seem to generally reduce root BVOC emissions under ambient conditions, but not under warmer climatic conditions.

\section{Atmospheric Reactions and the Effects of Climate Change}

Ecosystem resilience to changes in abiotic conditions is based on the capacity of vegetation to adapt to these changes. BVOCs produced in plant cells are central to plant adaption to temperature and drought stress [60]. BVOC emissions are also part of the biosphere-atmosphere loop where ecosystem BVOC emissions link aerosols and clouds in forest ecosystems [125-128]. If climate change continues at its current rate, there is a clear risk that resilience of forest ecosystems will be jeopardised resulting in substantial changes to ecosystem structure and function [129].

Common BVOCs belonging to the same chemical group may have high variability in their reactivity with major atmospheric oxidants. Highly reactive compounds degrade the fastest in atmospheric reactions and have short atmospheric lifetimes (Table 4). The molecular structure of each compound affects its reactivity, and the higher the number of double bonds the higher the reactivity with atmospheric oxidants [130,131]. BVOCs released into the atmosphere such as monoterpenes are transformed into low-volatility organic compounds in atmospheric reactions within a few hours [132-135]. Further oxidation of these first-generation low-volatility compounds produces progressively less-volatile products that will initiate biogenic secondary organic aerosol (BSOA) particle formation and growth by condensation in the atmosphere [132-135].

Table 4. Examples of calculated atmospheric lifetimes of some constitutively emitted and herbivore-induced BVOCs in reactions with major reactive atmospheric oxidants. BVOC classes: $\mathrm{I}=$ isoprene, $\mathrm{MT}=$ monoterpene, $\mathrm{SQT}=$ sesquiterpene, $\mathrm{HT}=$ homoterpene, $\mathrm{GLV}=\mathrm{C} 6$ green leaf volatile. Major oxidants: $\mathrm{OH}=$ hydroxyl radical, $\mathrm{O}_{3}=$ ozone, $\mathrm{NO}_{3}=$ nitrate radical .

\begin{tabular}{|c|c|c|c|c|c|}
\hline \multirow[t]{2}{*}{ VOCs } & \multirow{2}{*}{$\begin{array}{c}\text { BVOC } \\
\text { Type }\end{array}$} & \multicolumn{4}{|c|}{ Lifetimes for Reaction with Oxidants } \\
\hline & & $\mathrm{OH}^{\mathrm{a}}$ & $\mathrm{O}_{3} \mathrm{~b}$ & $\mathrm{NO}_{3}{ }^{\mathrm{c}}$ & Ref \\
\hline \multicolumn{6}{|l|}{ Constitutively emitted compounds } \\
\hline Methanol & Oxygenate & 12 day & $>4.5$ year & 2.0 year & [130] \\
\hline Isoprene & I & $1.4 \mathrm{~h}$ & 1.3 day & $1.6 \mathrm{~h}$ & [130] \\
\hline 3-carene & MT & $1.6 \mathrm{~h}$ & $11 \mathrm{~h}$ & $7 \mathrm{~min}$ & [130] \\
\hline Limonene & MT & $49 \mathrm{~min}$ & $2.0 \mathrm{~h}$ & $5 \mathrm{~min}$ & [130] \\
\hline$\alpha$-Pinene & MT & $2.6 \mathrm{~h}$ & $4.6 \mathrm{~h}$ & $11 \mathrm{~min}$ & [130] \\
\hline Longifolene & SQT & $2.9 \mathrm{~h}$ & $>33$ day & $1.6 \mathrm{~h}$ & [130] \\
\hline \multicolumn{6}{|l|}{ Typical herbivore-inducible compounds } \\
\hline cis-/trans-Ocimene & MT & $33 \mathrm{~min}$ & $44 \mathrm{~min}$ & $3 \mathrm{~min}$ & [130] \\
\hline$\beta$-Phellandrene & MT & $50 \mathrm{~min}$ & $8.4 \mathrm{~h}$ & $8 \mathrm{~min}$ & [130] \\
\hline$\beta$-Caryophyllene & SQT & $42 \mathrm{~min}$ & $2 \mathrm{~min}$ & $3 \mathrm{~min}$ & [130] \\
\hline$\beta$-Farnesene & SQT & $1.0 \mathrm{~h}$ & $14 \mathrm{~min}$ & & {$[131,136]$} \\
\hline DMNT (4,8-dimethyl-1,3,7 nonatriene) & HT & $40 \mathrm{~min}$ & $60 \mathrm{~min}$ & $3 \mathrm{~min}$ & [137] \\
\hline cis-3-Hexenyl acetate & GLV & $1.8 \mathrm{~h}$ & $7.3 \mathrm{~h}$ & $4.5 \mathrm{~h}$ & [130] \\
\hline cis-3-Hexen-1-ol & GLV & $1.3 \mathrm{~h}$ & $6.2 \mathrm{~h}$ & $4.1 \mathrm{~h}$ & [130] \\
\hline cis-3-Hexenal & GLV & & $2 \mathrm{~h}$ & & [131] \\
\hline Methyl salicylate & Aromatics & & $52 \mathrm{~h}$ & & [131] \\
\hline
\end{tabular}

Oxidant concentrations used in calculation [130]: ( $\left.{ }^{\mathrm{a}}\right)$ Assumed $\mathrm{OH}$ radical concentration: $2.0 \times 10^{6}$ molecule $\mathrm{cm}^{-3}, 12$-h daytime average. $\left({ }^{b}\right)$ Assumed $\mathrm{O}_{3}$ concentration: $7 \times 10^{11}$ molecule $\mathrm{cm}^{-3}(30 \mathrm{ppb})$, 24-h average. $\left({ }^{\mathrm{c}}\right)$ Assumed $\mathrm{NO}_{3}$ radical concentration: $2.5 \times 10^{8}$ molecule $\mathrm{cm}^{-3}, 12$-h nighttime average.

As discussed in earlier sections, BVOC emission rates and emission profiles will change in a warming climate due to both increasing temperature and expected increases in herbivore outbreaks. In general, the increase in emission rates will increase the gas phase concentration of BVOC, and hence enhance BSOA formation through atmospheric oxidation processes $[138,139]$. However, the exact effect of increased BVOC emissions on the formed BSOA mass is complicated and depends strongly on how the BVOC emission profiles will change with increasing temperature in different environments. These com- 
plications are due to the reactivities of different BVOCs with atmospheric oxidants and the vapor pressure of the oxidation products formed. Furthermore, the BSOA mass yields depend strongly on the structure and chemical characteristics of precursor BVOCs.

It has been thought, for example, that the sesquiterpene to monoterpene ratio could control the volatility of oxidation products and consequently the BSOA yields, whereby an increasing fraction of sesquiterpenes would decrease the volatility of oxidation products and increase the yield. However, more detailed investigations have shown that, as well as this ratio, the specific type of the terpene whose fraction is changing defines how the volatility of oxidation products and the subsequent BSOA yield changes. Faiola et al. [92] reported increases in SOA yields with an increasing contribution of sesquiterpenes in experiments whereby $\beta$-carophyllene contributed most to the sesquiterpene load. However, rather contrasting results by Faiola et al. [140] and Ylisirniö et al. [30] show that when farnesene was the dominant sesquiterpene species, there was a trend for a decrease in SOA yields in photo-oxidation (with both $\mathrm{O}_{3}$ and $\mathrm{OH}$ present) experiments with an increasing sesquiterpene ratio. The reason for the different behavior of the two sesquiterpene types is based on their molecular structure. Bicyclic compounds, such as $\beta$-carophyllene, have one endo- and one exocyclic $\mathrm{C}=\mathrm{C}$ bond, while acyclic compounds (e.g., farnesene) have four $\mathrm{C}=\mathrm{C}$ bonds. In the (photo-)oxidation process, the carbon backbone of acyclic compounds is fragmented into smaller pieces because both $\mathrm{O}_{3}$ and $\mathrm{OH}$ break the $\mathrm{C}=\mathrm{C}$ bonds efficiently. Just a single oxidation step can decrease the number of carbons from 15 to $5-12$ [136,141]. In the case of the bicyclic compounds, fragmentation is expected to be much less prominent $[142,143]$. Furthermore, it has been shown that changing monoterpene emission profiles due to pine weevil feeding greatly affects SOA mass yields [140]. This observation is supported by results showing that an increased fraction of monoterpenes with endocyclic $\mathrm{C}=\mathrm{C}$ bonds increases the SOA yield [30]. Measurements of SOA yields of $\alpha$-phellandrene, which has an endocyclic $\mathrm{C}=\mathrm{C}$ bond, showed that the SOA yield was about twice that of $\alpha$-pinene, reaching up to $100 \%$ [144].

According to Faiola et al. [92] specific monoterpene emission profiles can play a critical role in controlling SOA yields, particularly when the sesquiterpene to monoterpene ratio is small (less than 0.1 ). The complexity of oxidation chemistry and yields of different terpene classes and differences between and also within the same terpene classes should be considered in more detail in future studies. In many climate models, $\alpha$-pinene (monoterpene) and isoprene are considered as model compounds for predicting BSOA formation from plant emissions.

In addition to affecting the overall formation of BSOA, changing BVOC profiles may have an effect on the physical and chemical characteristics of the BSOA formed. It has been shown that precursor VOCs greatly affect, e.g., the hygroscopicity and the physical phase state of SOA particles (e.g., [145-148]). SOA from sesquiterpene oxidation generally has lower hygroscopicity and maintains a semi-solid or solid physical phase state at higher humidity conditions than monoterpene- or isoprene-derived SOA. Hence the changes in BVOC emissions profiles due to increased temperature and herbivore outbreaks may also affect the cloud condensation nuclei (CCN) and ice nuclei (IN) activity of BSOA. Therefore, changing BVOC emissions might influence atmospheric $\mathrm{CCN}$ concentration and consequently the indirect effects of aerosols in two different ways:(1) by changing the amount of BSOA in the atmosphere and (2) by changing the CCN and IN properties of formed SOA.

The observational data for the loadings of BSOA and CCN in the atmosphere demonstrate that increased temperature will likely increase BVOC emissions, the formed BSOA, and hence the CCN concentrations in the atmosphere $[138,139,149]$. Furthermore, Yli-Juuti et al. [149] have recently shown that in the boreal region temperature driven increases in BSOA loadings result in significant increases in both the aerosol optical depth (AOD) and cloud albedo analyzed using satellite observations. 


\section{Herbivore Damage Effects on Secondary Aerosol Formation in the Atmosphere}

Our knowledge of the effects of herbivore-induced emissions of forest trees on atmospheric SOA formation is still sparse $[114,135]$ and has only been experimentally tested in a few studies $[30,31,91,92,127,140,150]$. Some outbreak species, such as L. dispar, consume foliage at a relatively fast rate, which leads to the loss of VOC-emitting leaf material, but also leads to physiological disturbances in intact leaves that reduce photosynthesis. In isoprene-emitting trees, such as Quercus robur, isoprene emission is reduced while damaged leaves emit higher rates of herbivore-induced VOCs [151]. Herbivore-feeding on deciduous birch foliage results in emission of highly reactive GLVs within minutes of damage [50], and these emissions are known to be related to SOA formation [152]. Betula species are important monoterpene and sesquiterpene emitters also [31,68,153]. Within $24 \mathrm{~h}$ of feeding initiation, increased emission of monoterpenes, sesquiterpenes and the homoterpene (E)-4,8-Dimethyl-1,3,7-nonatriene (DMNT) are detected [31]. Numerous compounds in the chemical groups are highly reactive with atmospheric oxidants such as ozone $[31,154,155]$.

In a laboratory exposure experiment, deciduous mountain birch BVOC emissions and subsequent SOA particle formation rates and mass yields from reactions with ozone were measured during folivory by an outbreaking geometrid moth E. autumnata. The results showed that increased larval density strongly stimulated herbivore-induced BVOC emissions. When compared to controls without damage, a distinctive formation of new particles via nucleation in the reaction chamber was observed, and the SOA mass loadings from damaged seedlings increased by up to 150-fold [31]. However, a later study [30] testing the effects of an E. autumnata outbreak on atmospheric quality and aerosol particle concentrations above an attacked mountain birch forest did not find a direct correlation between the larval density and aerosol particle growth rate or the total particle concentration. Interestingly, the analysis of total aerosol particle concentrations suggested that they were elevated for 2-3 years after an initial infestation by the larvae. The authors suggested that it may be an indication of delayed defense responses, such as herbivory stimulated regrowth of mountain birch. However, the damage intensity might have been too low to affect SOA formation to draw any clear conclusions [30]. Among the herbivore induced BVOCs of mountain birch, sesquiterpenes have been shown to have delayed induction, which can occur for a couple of years after the end of an outbreak [156]. In several studies on conifers, biotic stress-induced BVOC emissions have been linked to SOA formation in $\mathrm{O}_{3}$ and $\mathrm{OH}$-induced atmospheric reactions $[91,114,157]$. Feeding by chewing insects induces monoterpene-dominated BVOC emissions at the feeding sites on the plant $[10,44]$ and in distal needles [44]. Emissions of some herbivore-induced sesquiterpenes such as (E)- $\beta$-farnesene, were only detected from individual needles infested by the needle-feeding spider mite Oligonychus ununguis. [158]. Damage by chewing insects will result in resin flow from damaged needle residues, such as needle stumps [10]. Bark feeding insects such as weevils $[44,93]$ and bark beetles $[10,159,160]$ produce significant damage to resinstoring tissues and cause monoterpene-releasing resin flow. Conifer bark-feeding aphids (Cinara spp.) induce emission of bicyclic monoterpenes [161], sesquiterpenes [140], and methyl salicylate [106,157].

Temperature is affecting forest BVOC emissions and formation of SOA in the atmosphere and thus warmer and longer summer temperature and extended growing season will increase biogenic SOA formation in the atmosphere [162]. Any specific studies testing the interactions between temperature and herbivore induced BVOC emission rates and SOA formation in boreal forest atmospheres have not yet been published. With agricultural plants, an elevating temperature is positively affecting herbivore-induced BVOC emission rates with the highest in the temperature range of 22 to $27^{\circ} \mathrm{C}$ under sufficient daylight [163]. Above $20^{\circ} \mathrm{C}$ degree "nightless night" conditions are encountered in the subarctic and northern boreal zones for close to $24 \mathrm{~h}$ per day in midsummer.

Joutsensaari et al. [91] analyzed pine sawfly feeding effects on Scots pine needle BVOC emission rates in field experiments and demonstrated 11-fold and 20-fold increases in monoterpene and sesquiterpene emissions, respectively. Laboratory measurements of 
BVOCs emitted by the bark of Scots pine and Norway spruce seedlings showed 10-50 fold increases in BVOC emissions in response to bark weevil feeding; subsequent reactions with elevated ozone led to 200-1000-fold increases in SOA masses formed compared to SOA masses from reactions with BVOCs emitted by undamaged seedlings. On the basis of these results, a global-scale model projecting a 10-fold increase in monoterpene emission in $10 \%$ of the boreal conifer forest area showed significant increases in aerosol masses and a $45 \%$ increase in aerosol-cloud condensation-nuclei $(\mathrm{CNN})$ concentrations [91]. These results were verified with satellite monitoring data of aerosol optical density that have shown an increased density of aerosols in the atmosphere above conifer forests attacked by mountain bark beetles in Canada [91]. SOA formed from BVOC reactions were separated from aerosol particles released, e.g., from wild fires, although in some active wild fire periods separation is not particularly efficient. However, forest fires and their aerosol production are partly an indirect result of trees dying in the older beetle outbreak areas. Most importantly, aerosols formed from burning contain black carbon and, thus, have a warming effect in the atmosphere while SOA originating from BVOC emissions mostly act as a sunscreen and has a cooling effect in the atmosphere [164].

The 10 fold increase in reactive BVOC emissions after bark beetle damage and significant increase in SOA mass in atmospheric reactions leading to increases in CNN concentration in the atmosphere [91], suggests that after extensive insect outbreaks in conifer forests there could be climatic-cooling via secondary aerosol and cloud formation. The rate of isoprene emission has been linked to the suppression of new particle formation by scavenging hydroxyl radicals that would react with other terpenes [48]. In boreal conifer forest, the proportion of isoprene emissions is lower than, e.g., from the subarctic peatlands where isoprene could be the dominant BVOC [7] and emissions are increased by warming [8]. Hence, due to high isoprene emissions from peatland sites the induced BVOC emissions from defoliating moth outbreaks on mountain birches in the subarctic might not result in distinctive SOA and CCN formation [30] as in boreal conifer forest after insect outbreaks.

\section{Conclusions and Future Directions}

There is a clear need to better understand the adaptation of boreal and subarctic forest ecosystems to a warming climate. BVOCs are a crucial part of intra- and interspecies communication in forest ecosystems, as well as a major component of biosphereatmosphere interactions. This means that dramatic disturbances in ecosystem function under climate change may disturb the biosphere-atmosphere feedbacks and then loosen or reinforce the control of climatic trends, such as warming. A good example of the ecosystem change-climate feedback is the loss of permafrost in the Arctic, Antarctic, and alpine regions under climate warming. The flux of major greenhouse gases $\mathrm{CO}_{2}, \mathrm{CH}_{4}$, and $\mathrm{N}_{2} \mathrm{O}$ from soil to the atmosphere will increase substantially during permafrost thawing [165], which has the potential to directly accelerate climate warming. Permafrost thawing may also increase BVOC emissions from soil in the Arctic, but increased microbial activity in the upper soil layer will consume these non-methane BVOCs and regulate their release to the atmosphere [166].

Herbivore-feeding and oviposition have been reported to affect BVOC emissions. To date, the majority of herbivores studied have consumed aboveground parts of plants and BVOC responses aboveground have been focused upon. There are, as yet, few experiments that have investigated the effects of feeding by herbivores either above or belowground on the emissions from the roots and rhizosphere. H. abietis-commonly studied for its effects on aboveground plant parts—-has been observed to feed [167] and oviposit [168] in root bark, which is likely to affect BVOC emissions [43]. To gain greater insight into the full effects of herbivores and climate on biosphere-atmosphere feedbacks, greater attention should be paid to belowground processes induced by herbivores.

It is also important to note that few studies have considered potential invasive herbivore species in predicting future BVOC scenarios. Invasion of flying herbivores is much more rapid than invasion of new plant species and invasive herbivores may reach outbreak 
levels in future conditions. While invasive herbivores may outbreak on plant species currently present in the more northern areas, over a longer time scale new invasive plant species will have their own herbivores arriving. Hence, more studies of how warming and potential invasive herbivore species affect BVOC emissions will provide important information in this topic. Since earlier studies under open field conditions have typically investigated one temperature elevation level, there is a need to gain information on response thresholds by conducting warming experiments with several temperature elevations levels in interaction with herbivory. It is known that after emission BVOCs will influence SOA formation, which will further affect climate, but knowledge of warmingand herbivore-induced BVOC impacts on atmospheric SOA formation is still incomplete.

Funding: The writing of this review was supported by Academy of Finland decision number 309425, and a University of Eastern Finland Doctoral Program grant to Hao Yu.

Institutional Review Board Statement: Not applicable.

Informed Consent Statement: Not applicable.

Data Availability Statement: Not applicable.

Conflicts of Interest: The authors declare no conflict of interest.

\section{References}

1. Post, E.; Forchhammer, M.C.; Bret-Harte, M.S.; Callaghan, T.V.; Christensen, T.R.; Elberling, B.; Fox, A.D.; Gilg, O.; Hik, D.S.; Høye, T.T.; et al. Ecological Dynamics Across the Arctic Associated with Recent Climate Change. Science 2009, 325, 1355-1358. [CrossRef]

2. Overland, J.E.; Wang, M.Y.; Walsh, J.E.; Stroeve, J.C. Future Arctic climate changes: Adaptation and mitigation time scales. Earths Future 2014, 2, 68-74. [CrossRef]

3. Phrampus, B.J.; Hornbach, M.J. Recent changes to the Gulf Stream causing widespread gas hydrate destabilization. Nature 2012, 490, 527-529. [CrossRef]

4. Marushchak, M.E.; Pitkämäki, A.; Koponen, H.; Biasi, C.; Seppälä, M.; Martikainen, P.J. Hot spots for nitrous oxide emissions found in different types of permafrost peatlands. Glob. Chang. Biol. 2011, 17, 2601-2614. [CrossRef]

5. DeConto, R.M.; Galeotti, S.; Pagani, M.; Tracy, D.; Schaefer, K.; Zhang, T.J.; Pollard, D.; Beerling, D.J. Past extreme warming events linked to massive carbon release from thawing permafrost. Nature 2012, 484, 87-91. [CrossRef] [PubMed]

6. Voigt, C.; Marushchak, M.E.; Lamprecht, R.E.; Jackowicz-Korczyński, M.; Lindgren, A.; Mastepanov, M.; Granlund, L.; Christensen, T.R.; Tahvanainen, T.; Martikainen, P.J.; et al. Increased nitrous oxide emissions from Arctic peatlands after permafrost thaw. Proc. Natl. Acad. Sci. USA 2017, 114, 6238-6243. [CrossRef] [PubMed]

7. Seco, R.; Holst, T.; Matzen, M.S.; Westergaard-Nielsen, A.; Li, T.; Simin, T.; Jansen, J.; Crill, P.; Friborg, T.; Rinne, J.; et al. Volatile organic compound fluxes in a subarctic peatland and lake. Atmos. Chem. Phys. 2020, 20, 13399-13416. [CrossRef]

8. Faubert, P.; Tiiva, P.; Nakam, T.A.; Holopainen, J.K.; Holopainen, T.; Rinnan, R. Non-methane biogenic volatile organic compound emissions from boreal peatland microcosms under warming and water table drawdown. Biogeochemistry 2011, 106, 503-516. [CrossRef]

9. Kivimäenpää, M.; Ghimire, R.P.; Sutinen, S.; Häikiö, E.; Kasurinen, A.; Holopainen, T.; Holopainen, J.K. Increases in volatile organic compound emissions of Scots pine in response to elevated ozone and warming are modified by herbivory and soil nitrogen availability. Eur. J. For. Res. 2016, 135, 343-360. [CrossRef]

10. Ghimire, R.P.; Markkanen, J.M.; Kivimäenpää, M.; Lyytikäinen-Saarenmaa, P.; Holopainen, J.K. Needle Removal by pine sawfly larvae increases branch-level VOC emissions and reduces below-ground emissions of Scots pine. Environ. Sci. Technol. 2013, 47, 4325-4332. [CrossRef] [PubMed]

11. Eller, A.S.D.; Harley, P.; Monson, R.K. Potential contribution of exposed resin to ecosystem emissions of monoterpenes. Atmos. Environ. 2013, 77, 440-444. [CrossRef]

12. Lin, C.; Owen, S.M.; Peñuelas, J. Volatile organic compounds in the roots and rhizosphere of Pinus spp. Soil Biol. Biochem. 2007, 39, 951-960. [CrossRef]

13. Rasheed, M.U.; Kasurinen, A.; Kivimäenpää, M.; Ghimire, R.; Häikiö, E.; Mpamah, P.; Holopainen, J.K.; Holopainen, T. The responses of shoot-root-rhizosphere continuum to simultaneous fertilizer addition, warming, ozone and herbivory in young Scots pine seedlings in a high latitude field experiment. Soil Biol. Biochem. 2017, 114, 279-294. [CrossRef]

14. Mäki, M.; Krasnov, D.; Hellén, H.; Noe, S.M.; Bäck, J. Stand type affects fluxes of volatile organic compounds from the forest floor in hemiboreal and boreal climates. Plant Soil 2019, 441, 363-381. [CrossRef]

15. Kivimäenpää, M.; Magsarjav, N.; Ghimire, R.; Markkanen, J.M.; Heijari, J.; Vuorinen, M.; Holopainen, J.K. Influence of tree provenance on biogenic VOC emissions of Scots pine (Pinus sylvestris) stumps. Atmos. Environ. 2012, 60, 477-485. [CrossRef] 
16. Walker, T.W.N.; Janssens, I.A.; Weedon, J.T.; Sigurdsson, B.D.; Richter, A.; Peñuelas, J.; Leblans, N.I.W.; Bahn, M.; Bartrons, M.; De Jonge, C.; et al. A systemic overreaction to years versus decades of warming in a subarctic grassland ecosystem. Nat. Ecol. Evol. 2020, 4, 101-108. [CrossRef] [PubMed]

17. Peñuelas, J.; Boada, M. A global change-induced biome shift in the Montseny mountains (NE Spain). Glob. Chang. Biol. 2003, 9 , 131-140. [CrossRef]

18. Kellomäki, S.; Rouvinen, I.; Peltola, H.; Strandman, H.; Steinbrecher, R. Impact of global warming on the tree species composition of boreal forests in Finland and effects on emissions of isoprenoids. Glob. Chang. Biol. 2001, 7, 531-544. [CrossRef]

19. Boisvert-Marsh, L.; Périé, C.; de Blois, S. Shifting with climate? Evidence for recent changes in tree species distribution at high latitudes. Ecosphere 2014, 5, 83. [CrossRef]

20. Myers-Smith, I.H.; Hik, D.S. Climate warming as a driver of tundra shrubline advance. J. Ecol. 2018, 106, 547-560. [CrossRef]

21. Rinnan, R.; Iversen, L.L.; Tang, J.; Vedel-Petersen, I.; Schollert, M.; Schurgers, G. Separating direct and indirect effects of rising temperatures on biogenic volatile emissions in the Arctic. Proc. Natl. Acad. Sci. USA 2020, 117, 32476-32483. [CrossRef]

22. Torssonen, P.; Strandman, H.; Kellomäki, S.; Kilpeläinen, A.; Jylhä, K.; Asikainen, A.; Peltola, H. Do we need to adapt the choice of main boreal tree species in forest regeneration under the projected climate change? Forestry 2015, 88, 564-572. [CrossRef]

23. Scheffers, B.R.; De Meester, L.; Bridge, T.C.L.; Hoffmann, A.A.; Pandolfi, J.M.; Corlett, R.T.; Butchart, S.H.M.; Pearce-Kelly, P.; Kovacs, K.M.; Dudgeon, D.; et al. The broad footprint of climate change from genes to biomes to people. Science $2016,354$. [CrossRef] [PubMed]

24. Vanhanen, H.; Veleli, T.O.; Päivinen, S.; Kellomäki, S.; Niemelä, P. Climate change and range shifts in two insect defoliators: Gypsy moth and nun moth-A model study. Silva Fenn. 2007, 41, 621-638. [CrossRef]

25. Fält-Nardmann, J.J.J.; Tikkanen, O.P.; Ruohomäki, K.; Otto, L.F.; Leinonen, R.; Pöyry, J.; Saikkonen, K.; Neuvonen, S. The recent northward expansion of Lymantria monacha in relation to realised changes in temperatures of different seasons. For. Ecol. Manag. 2018, 427, 96-105. [CrossRef]

26. Romashkin, I.; Neuvonen, S.; Tikkanen, O.P. Northward shift in temperature sum isoclines may favour Ips typographus outbreaks in European Russia. Agric. For. Entomol. 2020, 22, 238-249. [CrossRef]

27. Jepsen, J.U.; Hagen, S.B.; Ims, R.A.; Yoccoz, N.G. Climate change and outbreaks of the geometrids Operophtera brumata and Epirrita autumnata in subarctic birch forest: Evidence of a recent outbreak range expansion. J. Anim. Ecol. 2008, 77, 257-264. [CrossRef] [PubMed]

28. Jepsen, J.U.; Kapari, L.; Hagen, S.B.; Schott, T.; Vindstad, O.P.L.; Nilssen, A.C.; Ims, R.A. Rapid northwards expansion of a forest insect pest attributed to spring phenology matching with sub-Arctic birch. Glob. Chang. Biol. 2011, 17, 2071-2083. [CrossRef]

29. Duan, C.S.; Zuo, S.D.; Wu, Z.F.; Qiu, Y.; Wang, J.F.; Lei, Y.H.; Liao, H.; Ren, Y. A review of research hotspots and trends in biogenic volatile organic compounds (BVOCs) emissions combining bibliometrics with evolution tree methods. Environ. Res. Lett. 2021, 16. [CrossRef]

30. Ylivinkka, I.; Itämies, J.; Klemola, T.; Ruohomäki, K.; Kulmala, M.; Taipale, D. Investigating evidence of enhanced aerosol formation and growth due to autumnal moth larvae feeding on mountain birch at SMEAR I in northern Finland. Boreal Environ. Res. 2020, 25, 121-143.

31. Yli-Pirilä, P.; Copolovici, L.; Kännaste, A.; Noe, S.; Blande, J.D.; Mikkonen, S.; Klemola, T.; Pulkkinen, J.; Virtanen, A.; Laaksonen, A.; et al. Herbivory by an outbreaking moth increases emissions of biogenic volatiles and leads to enhanced secondary organic aerosol formation capacity. Environ. Sci. Technol. 2016, 50, 11501-11510. [CrossRef]

32. Maffei, M.E. Sites of synthesis, biochemistry and functional role of plant volatiles. S. Afr. J. Bot. 2010, 76, 612-631. [CrossRef]

33. Dudareva, N.; Klempien, A.; Muhlemann, J.K.; Kaplan, I. Biosynthesis, function and metabolic engineering of plant volatile organic compounds. New Phytol. 2013, 198, 16-32. [CrossRef] [PubMed]

34. Adebesin, F.; Widhalm, J.R.; Boachon, B.; Lefèvre, F.; Pierman, B.; Lynch, J.H.; Alam, I.; Junqueira, B.; Benke, R.; Ray, S.; et al. Emission of volatile organic compounds from petunia flowers is facilitated by an ABC transporter. Science 2017, 356, 1386-1388. [CrossRef]

35. Himanen, S.J.; Blande, J.D.; Klemola, T.; Pulkkinen, J.; Heijari, J.; Holopainen, J.K. Birch (Betula spp.) leaves adsorb and re-release volatiles specific to neighbouring plants-A mechanism for associational herbivore resistance? New Phytol. 2010, 186, 722-732. [CrossRef] [PubMed]

36. Mofikoya, A.O.; Miura, K.; Ghimire, R.P.; Blande, J.D.; Kivimäenpää, M.; Holopainen, T.; Holopainen, J.K. Understorey Rhododendron tomentosum and leaf trichome density affect mountain birch voc emissions in the subarctic. Sci. Rep. 2018, 8, 13261. [CrossRef]

37. Misztal, P.K.; Hewitt, C.N.; Wildt, J.; Blande, J.D.; Eller, A.S.D.; Fares, S.; Gentner, D.R.; Gilman, J.B.; Graus, M.; Greenberg, J.; et al. Atmospheric benzenoid emissions from plants rival those from fossil fuels. Sci. Rep. 2015, 5, 12064. [CrossRef]

38. Šimpraga, M.; Ghimire, R.P.; Van Der Straeten, D.; Blande, J.D.; Kasurinen, A.; Sorvari, J.; Holopainen, T.; Adriaenssens, S.; Holopainen, J.K.; Kivimäenpää, M. Unravelling the functions of biogenic volatiles in boreal and temperate forest ecosystems. Eur. J. For. Res. 2019, 138, 763-787. [CrossRef]

39. Sun, Z.H.; Hüve, K.; Vislap, V.; Niinemets, Ü. Elevated $\mathrm{CO}_{2}$ magnifies isoprene emissions under heat and improves thermal resistance in hybrid aspen. J. Exp. Bot. 2013, 64, 5509-5523. [CrossRef] [PubMed] 
40. Ghimire, R.P.; Kivimäenpää, M.; Kasurinen, A.; Häikiö, E.; Holopainen, T.; Holopainen, J.K. Herbivore-induced BVOC emissions of Scots pine under warming, elevated ozone and increased nitrogen availability in an open-field exposure. Agric. For. Meteorol. 2017, 242, 21-32. [CrossRef]

41. Vanhatalo, A.; Chan, T.; Aalto, J.; Korhonen, J.F.; Kolari, P.; Hölttä, T.; Nikinmaa, E.; Bäck, J. Tree water relations can trigger monoterpene emissions from Scots pine stems during spring recovery. Biogeosciences 2015, 12, 5353-5363. [CrossRef]

42. Rissanen, K.; Vanhatalo, A.; Salmon, Y.; Bäck, J.; Hölttä, T. Stem emissions of monoterpenes, acetaldehyde and methanol from Scots pine (Pinus sylvestris L.) affected by tree-water relations and cambial growth. Plant Cell Environ. 2020, 43, 1751-1765. [CrossRef] [PubMed]

43. Tiiva, P.; Julkunen-Tiitto, R.; Häikiö, E.; Kasurinen, A. Belowground responses of Scots pine (Pinus sylvestris) seedlings to experimental warming, moderate nitrogen addition, and bark herbivory. Can. J. For. Res. 2019, 49, 647-660. [CrossRef]

44. Heijari, J.; Blande, J.D.; Holopainen, J.K. Feeding of large pine weevil on Scots pine stem triggers localised bark and systemic shoot emission of volatile organic compounds. Environ. Exp. Bot. 2011, 71, 390-398. [CrossRef]

45. Niinemets, Ü.; Kännaste, A.; Copolovici, L. Quantitative patterns between plant volatile emissions induced by biotic stresses and the degree of damage. Front. Plant Sci. 2013, 4, 262. [CrossRef]

46. Jiang, Y.F.; Ye, J.Y.; Veromann, L.L.; Niinemets, Ü. Scaling of photosynthesis and constitutive and induced volatile emissions with severity of leaf infection by rust fungus (Melampsora larici-populina) in Populus balsamifera var. suaveolens. Tree Physiol. 2016, 36, 856-872. [CrossRef]

47. Douma, J.C.; Ganzeveld, L.N.; Unsicker, S.B.; Boeckler, G.A.; Dicke, M. What makes a volatile organic compound a reliable indicator of insect herbivory? Plant Cell Environ. 2019, 42, 3308-3325. [CrossRef]

48. McCormick, A.C.; Irmisch, S.; Boeckler, G.A.; Gershenzon, J.; Köllner, T.G.; Unsicker, S.B. Herbivore-induced volatile emission from old-growth black poplar trees under field conditions. Sci. Rep. 2019, 9, 7714. [CrossRef]

49. Li, T.; Grauer-Gray, K.; Holopainen, J.K.; Blande, J.D. Herbivore gender effects on volatile induction in aspen and on olfactory responses in leaf beetles. Forests 2020, 11, 638. [CrossRef]

50. Maja, M.M.; Kasurinen, A.; Yli-Pirilä, P.; Joutsensaari, J.; Klemola, T.; Holopainen, T.; Holopainen, J.K. Contrasting responses of silver birch VOC emissions to short- and long-term herbivory. Tree Physiol. 2014, 34, 241-252. [CrossRef] [PubMed]

51. Portillo-Estrada, M.; Niinemets, Ü. Massive release of volatile organic compounds due to leaf midrib wounding in Populus tremula. Plant Ecol. 2018, 219, 1021-1028. [CrossRef] [PubMed]

52. Rissanen, K.; Hölttä, T.; Bäck, J. Transpiration directly regulates the emissions of water-soluble short-chained OVOCs. Plant Cell Environ. 2018, 41, 2288-2298. [CrossRef] [PubMed]

53. Grote, R.; Sharma, M.; Ghirardo, A.; Schnitzler, J.P. A new modeling approach for estimating abiotic and biotic stress-induced de novo emissions of biogenic volatile organic compounds from plants. Front. For. Glob. Chang. 2019, 2, 26. [CrossRef]

54. Werner, C.; Fasbender, L.; Romek, K.M.; Yáñez-Serrano, A.M.; Kreuzwieser, J. Heat waves change plant carbon allocation among primary and secondary metabolism altering $\mathrm{CO}_{2}$ assimilation, respiration, and voc emissions. Front. Plant Sci. 2020, 11, 1242 [CrossRef]

55. Seco, R.; Peñuelas, J.; Filella, I. Short-chain oxygenated VOCs: Emission and uptake by plants and atmospheric sources, sinks, and concentrations. Atmos. Environ. 2007, 41, 2477-2499. [CrossRef]

56. Von Dahl, C.C.; Hävecker, M.; Schlögl, R.; Baldwin, I.T. Caterpillar-elicited methanol emission: A new signal in plant-herbivore interactions? Plant J. 2006, 46, 948-960. [CrossRef]

57. Guenther, A.B.; Zimmerman, P.R.; Harley, P.C.; Monson, R.K.; Fall, R. Isoprene and monoterpene emission rate variability-model evaluations and sensitivity analyses. J. Geophys. Res. Atmos. 1993, 98, 12609-12617. [CrossRef]

58. Monson, R.K.; Jaeger, C.H.; Adams, W.W.; Driggers, E.M.; Silver, G.M.; Fall, R. Relationships among isoprene emission rate, photosynthesis, and isoprene synthase activity as influenced by temperature. Plant Physiol. 1992, 98, 1175-1180. [CrossRef]

59. Hüve, K.; Bichele, I.; Rasulov, B.; Niinemets, Ü. When it is too hot for photosynthesis: Heat-induced instability of photosynthesis in relation to respiratory burst, cell permeability changes and $\mathrm{H}_{2} \mathrm{O}_{2}$ formation. Plant Cell Environ. 2011, 34, 113-126. [CrossRef]

60. Loreto, F.; Schnitzler, J.P. Abiotic stresses and induced BVOCs. Trends Plant Sci. 2010, 15, 154-166. [CrossRef]

61. Tang, J.; Schurgers, G.; Valolahti, H.; Faubert, P.; Tiiva, P.; Michelsen, A.; Rinnan, R. Challenges in modelling isoprene and monoterpene emission dynamics of Arctic plants: A case study from a subarctic tundra heath. Biogeosciences 2016, 13, 6651-6667. [CrossRef]

62. Hartikainen, K.; Nerg, A.M.; Kivimäenpää, M.; Kontunen-Soppela, S.; Mäenpää, M.; Oksanen, E.; Rousi, M.; Holopainen, T. Emissions of volatile organic compounds and leaf structural characteristics of European aspen (Populus tremula) grown under elevated ozone and temperature. Tree Physiol. 2009, 29, 1163-1173. [CrossRef]

63. Silfver, T.; Heiskanen, L.; Aurela, M.; Myller, K.; Karhu, K.; Meyer, N.; Tuovinen, J.P.; Oksanen, E.; Rousi, M.; Mikola, J. Insect herbivory dampens Subarctic birch forest C sink response to warming. Nat. Commun. 2020, 11, 2529. [CrossRef] [PubMed]

64. Tiiva, P.; Häikiö, E.; Kasurinen, A. Impact of warming, moderate nitrogen addition and bark herbivory on BVOC emissions and growth of Scots pine (Pinus sylvestris L.) seedlings. Tree Physiol. 2018, 38, 1461-1475. [CrossRef]

65. Kivimäenpää, M.; Riikonen, J.; Ahonen, V.; Tervahauta, A.; Holopainen, T. Sensitivity of Norway spruce physiology and terpenoid emission dynamics to elevated ozone and elevated temperature under open-field exposure. Environ. Exp. Bot. 2013, 90, 32-42. [CrossRef] 
66. Maja, M.M.; Kasurinen, A.; Holopainen, T.; Julkunen-Tiitto, R.; Holopainen, J.K. The effect of warming and enhanced ultraviolet radiation on gender-specific emissions of volatile organic compounds from European aspen. Sci. Total Environ. 2016, $547,39-47$. [CrossRef] [PubMed]

67. Tiiva, P.; Faubert, P.; Michelsen, A.; Holopainen, T.; Holopainen, J.K.; Rinnan, R. Climatic warming increases isoprene emission from a subarctic heath. New Phytol. 2008, 180, 853-863. [CrossRef] [PubMed]

68. Hartikainen, K.; Riikonen, J.; Nerg, A.M.; Kivimäenpää, M.; Ahonen, V.; Tervahauta, A.; Kärenlampi, S.; Mäenpää, M.; Rousi, M.; Kontunen-Soppela, S.; et al. Impact of elevated temperature and ozone on the emission of volatile organic compounds and gas exchange of silver birch (Betula pendula Roth). Environ. Exp. Bot. 2012, 84, 33-43. [CrossRef]

69. Kajos, M. Emissions, Concentrations and Effects of BVOCs in the Boreal Atmosphere. Ph.D. Thesis, University of Helsinki, Helsinki, Finland, 2015.

70. Mamet, S.D.; Brown, C.D.; Trant, A.J.; Laroque, C.P. Shifting global Larix distributions: Northern expansion and southern retraction as species respond to changing climate. J. Biogeogr. 2019, 46, 30-44. [CrossRef]

71. Berner, L.T.; Beck, P.S.A.; Bunn, A.G.; Goetz, S.J. Plant response to climate change along the forest-tundra ecotone in northeastern Siberia. Glob. Chang. Biol. 2013, 19, 3449-3462. [CrossRef]

72. Ruuskanen, T.M.; Hakola, H.; Kajos, M.K.; Hellén, H.; Tarvainen, V.; Rinne, J. Volatile organic compound emissions from Siberian larch. Atmos. Environ. 2007, 41, 5807-5812. [CrossRef]

73. Powell, J.S.; Raffa, K.F. Effects of selected Larix laricina terpenoids on Lymantria dispar (Lepidoptera: Lymantriidae) development and behavior. Environ. Entomol. 1999, 28, 148-154. [CrossRef]

74. Hunter, M.D.; Varley, G.C.; Gradwell, G.R. Estimating the relative roles of top-down and bottom-up forces on insect herbivore populations: A classic study revisited. Proc. Natl. Acad. Sci. USA 1997, 94, 9176-9181. [CrossRef]

75. Broadley, H.J.; Kula, R.R.; Boettner, G.H.; Andersen, J.C.; Griffin, B.P.; Elkinton, J.S. Recruitment of native parasitic wasps to populations of the invasive winter moth in the northeastern United States. Biol. Invasions 2019, 21, 2871-2890. [CrossRef]

76. Büntgen, U.; Liebhold, A.; Nievergelt, D.; Wermelinger, B.; Roques, A.; Reinig, F.; Krusic, P.J.; Piermattei, A.; Egli, S.; Cherubini, P.; et al. Return of the moth: Rethinking the effect of climate on insect outbreaks. Oecologia 2020, 192, 543-552. [CrossRef] [PubMed]

77. Eriksson, M.; Neuvonen, S.; Roininen, H. Retention of wind-felled trees and the risk of consequential tree mortality by the European spruce bark beetle Ips typographus in Finland. Scand. J. For. Res. 2007, 22, 516-523. [CrossRef]

78. Virtanen, T.; Neuvonen, S.; Nikula, A.; Varama, M.; Niemelä, P. Climate change and the risks of Neodiprion sertifer outbreaks on Scots pine. Silva Fenn. 1996, 30, 169-177. [CrossRef]

79. Virtanen, T.; Neuvonen, S.; Nikula, A. Modelling topoclimatic patterns of egg mortality of Epirrita autumnata (Lepidoptera: Geometridae) with a Geographical Information System: Predictions for current climate and warmer climate scenarios. J. Appl. Ecol. 1998, 35, 311-322. [CrossRef]

80. Young, A.B.; Cairns, D.M.; Lafon, C.W.; Moen, J. Geometrid moth outbreaks and their climatic relations in northern Sweden. Arct. Antarct. Alp. Res. 2014, 46, 659-668. [CrossRef]

81. Kharuk, V.I.; Im, S.T.; Ranson, K.J.; Yagunov, M.N. Climate-Induced Northerly Expansion of Siberian Silkmoth Range. Forests 2017, 8, 301. [CrossRef] [PubMed]

82. Kharuk, V.I.; Im, S.T.; Soldatov, V.V. Siberian silkmoth outbreaks surpassed geoclimatic barrier in Siberian Mountains. J. Mt. Sci. 2020, 17, 1891-1900. [CrossRef]

83. Voolma, K.; Hiiesaar, K.; Williams, I.H.; Ploomi, A.; Jõgar, K. Cold hardiness in the pre-imaginal stages of the great web-spinning pine-sawfly Acantholyda posticalis. Agric. For. Entomol. 2016, 18, 432-436. [CrossRef]

84. Raffa, K.F.; Powell, E.N.; Townsend, P.A. Temperature-driven range expansion of an irruptive insect heightened by weakly coevolved plant defenses. Proc. Natl. Acad. Sci. USA 2013, 110, 2193-2198. [CrossRef]

85. Buotte, P.C.; Hicke, J.A.; Preisler, H.K.; Abatzoglou, J.T.; Raffa, K.F.; Logan, J.A. Recent and future climate suitability for whitebark pine mortality from mountain pine beetles varies across the western US. For. Ecol. Manag. 2017, 399, 132-142. [CrossRef]

86. Kautz, M.; Meddens, A.J.H.; Hall, R.J.; Arneth, A. Biotic disturbances in Northern Hemisphere forests-a synthesis of recent data, uncertainties and implications for forest monitoring and modelling. Glob. Ecol. Biogeogr. 2017, 26, 533-552. [CrossRef]

87. Dicke, M.; Baldwin, I.T. The evolutionary context for herbivore-induced plant volatiles: Beyond the 'cry for help'. Trends Plant Sci. 2010, 15, 167-175. [CrossRef] [PubMed]

88. Kroes, A.; Broekgaarden, C.; Uribe, M.C.; May, S.; van Loon, J.J.A.; Dicke, M. Brevicoryne brassicae aphids interfere with transcriptome responses of Arabidopsis thaliana to feeding by Plutella xylostella caterpillars in a density-dependent manner. Oecologia 2017, 183, 107-120. [CrossRef] [PubMed]

89. Caarls, L.; Pieterse, C.M.J.; Van Wees, S.C.M. How salicylic acid takes transcriptional control over jasmonic acid signaling. Front. Plant Sci. 2015, 6, 170. [CrossRef] [PubMed]

90. Litvak, M.E.; Monson, R.K. Patterns of induced and constitutive monoterpene production in conifer needles in relation to insect herbivory. Oecologia 1998, 114, 531-540. [CrossRef] [PubMed]

91. Joutsensaari, J.; Yli-Pirilä, P.; Korhonen, H.; Arola, A.; Blande, J.D.; Heijari, J.; Kivimäenpää, M.; Mikkonen, S.; Hao, L.; Miettinen, P.; et al. Biotic stress accelerates formation of climate-relevant aerosols in boreal forests. Atmos. Chem. Phys. 2015, 15, 12139-12157. [CrossRef] 
92. Faiola, C.L.; Buchholz, A.; Kari, E.; Yli-Pirilä, P.; Holopainen, J.K.; Kivimäenpää, M.; Miettinen, P.; Worsnop, D.R.; Lehtinen, K.E.J.; Guenther, A.B.; et al. Terpene composition complexity controls secondary organic aerosol yields from scots pine volatile emissions. Sci. Rep. 2018, 8, 3053. [CrossRef]

93. Kari, E.; Faiola, C.L.; Isokääntä, S.; Miettinen, P.; Yli-Pirilä, P.; Buchholz, A.; Kivimäenpää, M.; Mikkonenn, S.; Holopainen, J.K.; Virtanen, A. Time-resolved characterization of biotic stress emissions from Scots pines being fed upon by pine weevil by means of PTR-ToF-MS. Boreal Environ. Res. 2019, 24, 25-49.

94. Kovalchuk, A.; Raffaello, T.; Jaber, E.; Keriö, S.; Ghimire, R.; Lorenz, W.W.; Dean, J.F.D.; Holopainen, J.K.; Asiegbu, F.O. Activation of defence pathways in Scots pine bark after feeding by pine weevil (Hylobius abietis). BMC Genom. 2015, 16, 352. [CrossRef] [PubMed]

95. Blande, J.D.; Turunen, K.; Holopainen, J.K. Pine weevil feeding on Norway spruce bark has a stronger impact on needle VOC emissions than enhanced ultraviolet-B radiation. Environ. Pollut. 2009, 157, 174-180. [CrossRef] [PubMed]

96. Ghimire, R.P.; Kivimäenpää, M.; Blomqvist, M.; Holopainen, T.; Lyytikäinen-Saarenmaa, P.; Holopainen, J.K. Effect of bark beetle (Ips typographus L.) attack on bark VOC emissions of Norway spruce (Picea abies Karst.) trees. Atmos. Environ. 2016, 126, 145-152. [CrossRef]

97. Miller, B.; Madilao, L.L.; Ralph, S.; Bohlmann, J. Insect-induced conifer defense. White pine weevil and methyl jasmonate induce traumatic resinosis, de novo formed volatile emissions, and accumulation of terpenoid synthase and putative octadecanoid pathway transcripts in Sitka spruce. Plant Physiol. 2005, 137, 369-382. [CrossRef] [PubMed]

98. Lusebrink, I.; Erbilgin, N.; Eyenden, M.L. The effect of water limitation on volatile emission, tree defense response, and brood success of Dendroctonus ponderosae in two pine hosts, lodgepole, and jack pine. Front. Ecol. Evol. 2016, 4, 2. [CrossRef]

99. Priemé, A.; Knudsen, T.B.; Glasius, M.; Christensen, S. Herbivory by the weevil, Strophosoma melanogrammum, causes severalfold increase in emission of monoterpenes from young Norway spruce (Picea abies). Atmos. Environ. 2000, 34, 711-718. [CrossRef]

100. Mäntylä, E.; Alessio, G.A.; Blande, J.D.; Heijari, J.; Holopainen, J.K.; Laaksonen, T.; Piirtola, P.; Klemola, T. From Plants to birds: Higher avian predation rates in trees responding to insect herbivory. PLoS ONE 2008, 3, e2832. [CrossRef]

101. Rieksta, J.; Li, T.; Junker, R.R.; Jepsen, J.U.; Ryde, I.; Rinnan, R. Insect herbivory strongly modifies mountain birch volatile emissions. Front. Plant Sci. 2020, 11, 558979. [CrossRef]

102. Vuorinen, T.; Nerg, A.M.; Syrjälä, L.; Peltonen, P.; Holopainen, J.K. Epirrita autumnata induced VOC emission of silver birch differ from emission induced by leaf fungal pathogen. Arthropod-Plant Interact. 2007, 1, 159-165. [CrossRef]

103. Schaub, A.; Blande, J.D.; Graus, M.; Oksanen, E.; Holopainen, J.K.; Hansel, A. Real-time monitoring of herbivore induced volatile emissions in the field. Physiol. Plant. 2010, 138, 123-133. [CrossRef] [PubMed]

104. Blande, J.D.; Tiiva, P.; Oksanen, E.; Holopainen, J.K. Emission of herbivore-induced volatile terpenoids from two hybrid aspen (Populus tremula $x$ tremuloides) clones under ambient and elevated ozone concentrations in the field. Glob. Change Biol. 2007, 13, 2538-2550. [CrossRef]

105. Copolovici, L.; Kännaste, A.; Remmel, T.; Vislap, V.; Niinemets, Ü. Volatile emissions from Alnus glutinosa induced by herbivory are quantitatively related to the extent of damage. J. Chem. Ecol. 2011, 37, 18-28. [CrossRef] [PubMed]

106. Kivimäenpää, M.; Babalola, A.B.; Joutsensaari, J.; Holopainen, J.K. Methyl salicylate and sesquiterpene emissions are indicative for aphid infestation on scots pine. Forests 2020, 11, 573. [CrossRef]

107. Blande, J.D.; Korjus, M.; Holopainen, J.K. Foliar methyl salicylate emissions indicate prolonged aphid infestation on silver birch and black alder. Tree Physiol. 2010, 30, 404-416. [CrossRef]

108. Mumm, R.; Schrank, K.; Wegener, R.; Schulz, S.; Hilker, M. Chemical analysis of volatiles emitted by Pinus sylvestris after induction by insect oviposition. J. Chem. Ecol. 2003, 29, 1235-1252. [CrossRef]

109. Leather, S.R.; Day, K.R.; Salisbury, A.N. The biology and ecology of the large pine weevil, Hylobius abietis (Coleoptera: Curculionidae): A problem of dispersal? Bull. Entomol. Res. 1999, 89, 3-16. [CrossRef]

110. Alfaro, R.I.; Borden, J.H.; King, J.N.; Tomlin, E.S.; McIntosh, R.L.; Bohlmann, J. Mechanisms of resistance in conifers against shoot infesting insects. In Mechanisms and Deployment of Resistance in Trees to Insects; Wagner, M.R., Clancy, K.M., Lieutier, F., Paine, T.D., Eds.; Kluwer Academic Press: Dordrecht, The Netherlands, 2002; pp. 101-126.

111. Mondor, E.B.; Roland, J. Host locating behaviour of Leschenaultia exul and Patelloa pachypyga: Two tachinid parasitoids of the forest tent caterpillar, Malacosoma disstria. Entomol. Exp. Appl. 1997, 85, 161-168. [CrossRef]

112. Mondor, E.B.; Roland, J. Host searching and oviposition by Leschenaultia exul, a tachinid parasitoid of the forest tent caterpillar, Malacosoma disstria. J. Insect Behav. 1998, 11, 583-592. [CrossRef]

113. Havill, N.P.; Raffa, K.F. Compound effects of induced plant responses on insect herbivores and parasitoids: Implications for tritrophic interactions. Ecol. Entomol. 2000, 25, 171-179. [CrossRef]

114. Faiola, C.; Taipale, D. Impact of insect herbivory on plant stress volatile emissions from trees: A synthesis of quantitative measurements and recommendations for future research. Atmos. Environ. X 2020, 5, 100060. [CrossRef]

115. Yang, J.O.; Nakayama, N.; Toda, K.; Tebayashi, S.; Kim, C.S. Structural determination of elicitors in Sogatella furcifera (Horváth) that induce Japonica rice plant varieties (Oryza sativa L.) to produce an ovicidal substance against S. furcifera eggs. Biosci. Biotechnol. Biochem. 2014, 78, 937-942. [CrossRef]

116. Bruce, T.J.A.; Midega, C.A.O.; Birkett, M.A.; Pickett, J.A.; Khan, Z.R. Is quality more important than quantity? Insect behavioural responses to changes in a volatile blend after stemborer oviposition on an African grass. Biol. Lett. 2010, 6, 314-317. [CrossRef] [PubMed] 
117. Fatouros, N.E.; Lucas-Barbosa, D.; Weldegergis, B.T.; Pashalidou, F.G.; van Loon, J.J.A.; Dicke, M.; Harvey, J.A.; Gols, R.; Huigens, M.E. Plant Volatiles induced by herbivore egg deposition affect insects of different trophic levels. PLoS ONE 2012, 7, e43607. [CrossRef]

118. Holopainen, J.K.; Gershenzon, J. Multiple stress factors and the emission of plant VOCs. Trends Plant Sci. 2010, 15, 176-184. [CrossRef]

119. Moreira, X.; Abdala-Roberts, L.; Gols, R.; Francisco, M. Plant domestication decreases both constitutive and induced chemical defences by direct selection against defensive traits. Sci. Rep. 2018, 8, 12678. [CrossRef] [PubMed]

120. Noe, S.M.; Niinemets, Ü. Impact of Gall-Forming Insects on Global BVOC Emissions and Climate: A Perspective. Front. For. Glob. Chang. 2020, 3, 9. [CrossRef]

121. Arneth, A.; Schurgers, G.; Lathiere, J.; Duhl, T.; Beerling, D.J.; Hewitt, C.N.; Martin, M.; Guenther, A. Global terrestrial isoprene emission models: Sensitivity to variability in climate and vegetation. Atmos. Chem. Phys. 2011, 11, 8037-8052. [CrossRef]

122. Räisänen, T.; Ryyppö, A.; Kellomäki, S. Effects of elevated $\mathrm{CO}_{2}$ and temperature on monoterpene emission of Scots pine (Pinus sylvestris L.). Atmos. Environ. 2008, 42, 4160-4171. [CrossRef]

123. Kleist, E.; Mentel, T.F.; Andres, S.; Bohne, A.; Folkers, A.; Kiendler-Scharr, A.; Rudich, Y.; Springer, M.; Tillmann, R.; Wildt, J. Irreversible impacts of heat on the emissions of monoterpenes, sesquiterpenes, phenolic BVOC and green leaf volatiles from several tree species. Biogeosciences 2012, 9, 5111-5123. [CrossRef]

124. Rasheed, M.U.; Kivimäenpää, M.; Kasurinen, A. Emissions of biogenic volatile organic compounds (BVOCs) from the rhizosphere of Scots pine (Pinus sylvestris) seedlings exposed to warming, moderate $\mathrm{N}$ addition and bark herbivory by large pine weevil (Hylobius abietis). Plant Soil 2021. [CrossRef]

125. Tunved, P.; Hansson, H.C.; Kerminen, V.M.; Ström, J.; Dal Maso, M.; Lihavainen, H.; Viisanen, Y.; Aalto, P.P.; Komppula, M.; Kulmala, M. High natural aerosol loading over boreal forests. Science 2006, 312, 261-263. [CrossRef] [PubMed]

126. Bonan, G.B. Forests and climate change: Forcings, feedbacks, and the climate benefits of forests. Science 2008, 320, 1444-1449. [CrossRef] [PubMed]

127. Zhao, D.F.; Buchholz, A.; Tillmann, R.; Kleist, E.; Wu, C.; Rubach, F.; Kiendler-Scharr, A.; Rudich, Y.; Wildt, J.; Mentel, T.F. Environmental conditions regulate the impact of plants on cloud formation. Nat. Commun. 2017, 8, 14067. [CrossRef] [PubMed]

128. Sheil, D. Forests, atmospheric water and an uncertain future: The new biology of the global water cycle. For. Ecosyst. 2018, 5, 19. [CrossRef]

129. Peñuelas, J.; Sardans, J.; Filella, I.; Estiarte, M.; Llusià, J.; Ogaya, R.; Carnicer, J.; Bartrons, M.; Rivas-Ubach, A.; Grau, O.; et al. Assessment of the impacts of climate change on Mediterranean terrestrial ecosystems based on data from field experiments and long-term monitored field gradients in Catalonia. Environ. Exp. Bot. 2018, 152, 49-59. [CrossRef]

130. Atkinson, R.; Arey, J. Gas-phase tropospheric chemistry of biogenic volatile organic compounds: A review. Atmos. Environ. 2003, 37, S197-S219. [CrossRef]

131. Arneth, A.; Niinemets, Ü. Induced BVOCs: How to bug our models? Trends Plant Sci. 2010, 15, 118-125. [CrossRef] [PubMed]

132. Tröstl, J.; Chuang, W.K.; Gordon, H.; Heinritzi, M.; Yan, C.; Molteni, U.; Ahlm, L.; Frege, C.; Bianchi, F.; Wagner, R.; et al. The role of low-volatility organic compounds in initial particle growth in the atmosphere. Nature 2016, 533, 527-531. [CrossRef]

133. Ehn, M.; Thornton, J.A.; Kleist, E.; Sipilä, M.; Junninen, H.; Pullinen, I.; Springer, M.; Rubach, F.; Tillmann, R.; Lee, B. A large source of low-volatility secondary organic aerosol. Nature 2014, 506, 476-479. [CrossRef] [PubMed]

134. Bianchi, F.; Kurtén, T.; Riva, M.; Mohr, C.; Rissanen, M.P.; Roldin, P.; Berndt, T.; Crounse, J.D.; Wennberg, P.O.; Mentel, T.F.; et al. Highly oxygenated organic molecules (hom) from gas-phase autoxidation involving peroxy radicals: A key contributor to atmospheric aerosol. Chem. Rev. 2019, 119, 3472-3509. [CrossRef] [PubMed]

135. Holopainen, J.K.; Kivimäenpää, M.; Nizkorodov, S.A. Plant-derived secondary organic material in the air and ecosystems. Trends Plant Sci. 2017, 22, 744-753. [CrossRef] [PubMed]

136. Kourtchev, I.; Bejan, I.; Sodeau, J.R.; Wenger, J.C. Gas phase reaction of OH radicals with (E)-beta-farnesene at $296+/-2$ K: Rate coefficient and carbonyl products. Atmos. Environ. 2012, 46, 338-345. [CrossRef]

137. Holopainen, J.K.; Nerg, A.M.; Blande, J.D. Multitrophic signalling in polluted atmospheres. In Biology, Controls and Models of Tree Volatile Organic Compound Emissions; Springer: Berlin/Heidelberg, Germany, 2013; pp. 285-314.

138. Goldstein, A.H.; Koven, C.D.; Heald, C.L.; Fung, I.Y. Biogenic carbon and anthropogenic pollutants combine to form a cooling haze over the southeastern United States. Proc. Natl. Acad. Sci. USA 2009, 106, 8835-8840. [CrossRef]

139. Paasonen, P.; Asmi, A.; Petäjä, T.; Kajos, M.K.; Äijälä, M.; Junninen, H.; Holst, T.; Abbatt, J.P.D.; Arneth, A.; Birmili, W.; et al. Warming-induced increase in aerosol number concentration likely to moderate climate change. Nat. Geosci. 2013, 6, 438-442. [CrossRef]

140. Faiola, C.L.; Pullinen, I.; Buchholz, A.; Khalaj, F.; Ylisirniö, A.; Kari, E.; Miettinen, P.; Holopainen, J.K.; Kivimäenpää, M.; Schobesberger, S.; et al. Secondary Organic Aerosol Formation from Healthy and Aphid-Stressed Scots Pine Emissions. ACS Earth Space Chem. 2019, 3, 1756-1772. [CrossRef]

141. Kourtchev, I.; Bejan, I.; Sodeau, J.R.; Wenger, J.C. Gas-phase reaction of (E)-beta-farnesene with ozone: Rate coefficient and carbonyl products. Atmos. Environ. 2009, 43, 3182-3190. [CrossRef]

142. Jaoui, M.; Leungsakul, S.; Kamens, R. Gas and particle products distribution from the reaction of $\beta$-caryophyllene with ozone. J. Atmos. Chem. 2003, 45, 261-287. [CrossRef] 
143. Jaoui, M.; Kleindienst, T.E.; Docherty, K.S.; Lewandowski, M.; Offenberg, J.H. Secondary organic aerosol formation from the oxidation of a series of sesquiterpenes: Alpha-cedrene, beta-caryophyllene, alpha-humulene and alpha-farnesene with $\mathrm{O}_{3}, \mathrm{OH}$ and $\mathrm{NO}_{3}$ radicals. Environ. Chem. 2013, 10, 178-193. [CrossRef]

144. Mackenzie-Rae, F.A.; Liu, T.Y.; Deng, W.; Saunders, S.M.; Fang, Z.; Zhang, Y.L.; Wang, X.M. Ozonolysis of alpha-phellandrene -Part 1: Gas- and particle-phase characterisation. Atmos. Chem. Phys. 2017, 17, 6583-6609. [CrossRef]

145. Saukko, E.; Lambe, A.T.; Massoli, P.; Koop, T.; Wright, J.P.; Croasdale, D.R.; Pedernera, D.A.; Onasch, T.B.; Laaksonen, A.; Davidovits, P.; et al. Humidity-dependent phase state of SOA particles from biogenic and anthropogenic precursors. Atmos. Chem. Phys. 2012, 12, 7517-7529. [CrossRef]

146. Rastak, N.; Pajunoja, A.; Navarro, J.C.A.; Ma, J.; Song, M.; Partridge, D.G.; Kirkevåg, A.; Leong, Y.; Hu, W.W.; Taylor, N.F.; et al. Microphysical explanation of the RH-dependent water affinity of biogenic organic aerosol and its importance for climate. Geophys. Res. Lett. 2017, 44, 5167-5177. [CrossRef] [PubMed]

147. Varutbangkul, V.; Brechtel, F.J.; Bahreini, R.; Ng, N.L.; Keywood, M.D.; Kroll, J.H.; Flagan, R.C.; Seinfeld, J.H.; Lee, A.; Goldstein, A.H. Hygroscopicity of secondary organic aerosols formed by oxidation of cycloalkenes, monoterpenes, sesquiterpenes, and related compounds. Atmos. Chem. Phys. 2006, 6, 2367-2388. [CrossRef]

148. Pajunoja, A.; Lambe, A.T.; Hakala, J.; Rastak, N.; Cummings, M.J.; Brogan, J.F.; Hao, L.Q.; Paramonov, M.; Hong, J.; Prisle, N.L.; et al. Adsorptive uptake of water by semisolid secondary organic aerosols. Geophys. Res. Lett. 2015, 42, 3063-3068. [CrossRef]

149. Yli-Juuti, T.; Mielonen, T.; Heikkinen, L.; Arola, A.; Ehn, M.; Isokääntä, S.; Kulmala, M.; Lipponen, A.; Mikkonen, S.; Nieminen, T.; et al. Direct evidence on temperature driven biosphere- atmosphere feedback through organic aerosols in boreal area. Nat. Commun. 2021. submitted.

150. Faiola, C.L.; Wen, M.; VanReken, T.M. Chemical characterization of biogenic secondary organic aerosol generated from plant emissions under baseline and stressed conditions: Inter- and intra-species variability for six coniferous species. Atmos. Chem. Phys. 2015, 15, 3629-3646. [CrossRef]

151. Copolovici, L.; Pag, A.; Kännaste, A.; Bodescu, A.; Tomescu, D.; Copolovici, D.; Soran, M.L.; Niinemets, Ü. Disproportionate photosynthetic decline and inverse relationship between constitutive and induced volatile emissions upon feeding of Quercus robur leaves by large larvae of gypsy moth (Lymantria dispar). Environ. Exp. Bot. 2017, 138, 184-192. [CrossRef]

152. Hamilton, J.F.; Lewis, A.C.; Carey, T.J.; Wenger, J.C.; Garcia, E.B.I.; Muñoz, A. Reactive oxidation products promote secondary organic aerosol formation from green leaf volatiles. Atmos. Chem. Phys. 2009, 9, 3815-3823. [CrossRef]

153. Wyche, K.P.; Ryan, A.C.; Hewitt, C.N.; Alfarra, M.R.; McFiggans, G.; Carr, T.; Monks, P.S.; Smallbone, K.L.; Capes, G.; Hamilton, J.F.; et al. Emissions of biogenic volatile organic compounds and subsequent photochemical production of secondary organic aerosol in mesocosm studies of temperate and tropical plant species. Atmos. Chem. Phys. 2014, 14, 12781-12801. [CrossRef]

154. Blande, J.D.; Holopainen, J.K.; Niinemets, Ü. Plant volatiles in polluted atmospheres: Stress responses and signal degradation. Plant Cell Environ. 2014, 37, 1892-1904. [CrossRef] [PubMed]

155. Mogensen, D.; Gierens, R.; Crowley, J.N.; Keronen, P.; Smolander, S.; Sogachev, A.; Nölscher, A.C.; Zhou, L.; Kulmala, M.; Tang, M.J.; et al. Simulations of atmospheric $\mathrm{OH}, \mathrm{O}_{3}$ and $\mathrm{NO}_{3}$ reactivities within and above the boreal forest. Atmos. Chem. Phys. 2015, 15, 3909-3932. [CrossRef]

156. Haapanala, S.; Ekberg, A.; Hakola, H.; Tarvainen, V.; Rinne, J.; Hellén, H.; Arneth, A. Mountain birch-potentially large source of sesquiterpenes into high latitude atmosphere. Biogeosciences 2009, 6, 2709-2718. [CrossRef]

157. Mentel, T.F.; Kleist, E.; Andres, S.; Dal Maso, M.; Hohaus, T.; Kiendler-Scharr, A.; Rudich, Y.; Springer, M.; Tillmann, R.; Uerlings, R.; et al. Secondary aerosol formation from stress-induced biogenic emissions and possible climate feedbacks. Atmos. Chem. Phys. 2013, 13, 8755-8770. [CrossRef]

158. Danielsson, M.; Zhaol, T.; Borg-Karlson, A.K. Arthropod infestation sites and induced defence can be traced by emission from single spruce needles. Arthropod-Plant Interact. 2019, 13, 253-259. [CrossRef]

159. Amin, H.; Atkins, P.T.; Russo, R.S.; Brown, A.W.; Sive, B.; Hallar, A.G.; Hartz, K.E.H. Effect of Bark Beetle Infestation on Secondary Organic Aerosol Precursor Emissions. Environ. Sci. Technol. 2012, 46, 5696-5703. [CrossRef] [PubMed]

160. Mageroy, M.H.; Christiansen, E.; Långström, B.; Borg-Karlson, A.K.; Solheim, H.; Björklund, N.; Zhao, T.; Schmidt, A.; Fossdal, C.G.; Krokene, P. Priming of inducible defenses protects Norway spruce against tree-killing bark beetles. Plant Cell Environ. 2020, 43, 420-430. [CrossRef] [PubMed]

161. Pettersson, M.; Unelius, C.R.; Valterova, I.; Borg-Karlson, A.K. Semiochemicals related to the aphid Cinara pilicornis and its host, Picea abies: A method to assign nepetalactone diastereomers. J. Chromatogr. 2008, 1180, 165-170. [CrossRef] [PubMed]

162. Kontkanen, J.; Paasonen, P.; Aalto, J.; Bäck, J.; Rantala, P.; Petäjä, T.; Kulmala, M. Simple proxies for estimating the concentrations of monoterpenes and their oxidation products at a boreal forest site. Atmos. Chem. Phys. 2016, 16, 13291-13307. [CrossRef]

163. Gouinguené, S.P.; Turlings, T.C.J. The effects of abiotic factors on induced volatile emissions in corn plants. Plant Physiol. 2002, 129, 1296-1307. [CrossRef]

164. Kulmala, M.; Luoma, K.; Virkkula, A.; Petäjä, T.; Paasonen, P.; Kerminen, V.M.; Nie, W.; Qi, X.M.; Shen, Y.C.; Chi, X.G.; et al. On the mode-segregated aerosol particle number concentration load: Contributions of primary and secondary particles in Hyytiala and Nanjing. Boreal Environ. Res. 2016, 21, 319-331.

165. Voigt, C.; Marushchak, M.E.; Abbott, B.W.; Biasi, C.; Elberling, B.; Siciliano, S.D.; Sonnentag, O.; Stewart, K.J.; Yang, Y.; Martikainen, P.J. Nitrous oxide emissions from permafrost-affected soils. Nat. Rev. Earth Environ. 2020, 1, 420-434. [CrossRef] 
166. Kramshøj, M.; Albers, C.N.; Holst, T.; Holzinger, R.; Elberling, B.; Rinnan, R. Biogenic volatile release from permafrost thaw is determined by the soil microbial sink. Nat. Commun. 2018, 9. [CrossRef]

167. Wallertz, K.; Nordlander, G.; Örlander, G. Feeding on roots in the humus layer by adult pine weevil, Hylobius abietis. Agric. For. Entomol. 2006, 8, 273-279. [CrossRef]

168. Azeem, M.; Rajarao, G.K.; Terenius, O.; Nordlander, G.; Nordenhem, H.; Nagahama, K.; Norin, E.; Borg-Karlson, A.K. A fungal metabolite masks the host plant odor for the pine weevil (Hylobius abietis). Fungal Ecol. 2015, 13, 103-111. [CrossRef] 